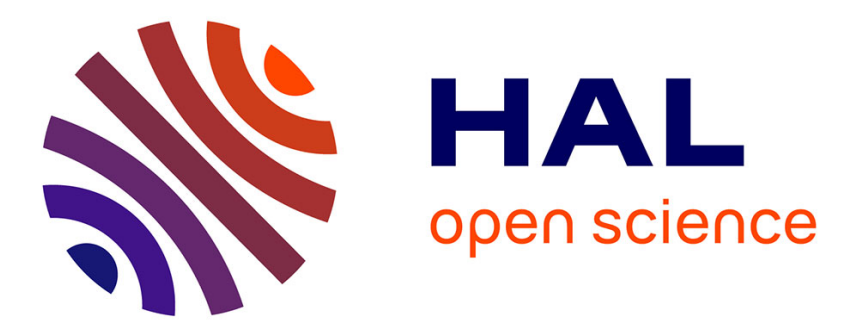

\title{
SJ23B, a jatrophane diterpene activates classical pkcs and displays strong activity against HIV
}

Luis M. Bedoya, Nieves Márquez, Natalia Martínez, Silvia Gutiérrez-Eisman, Amparo Álvarez, Marco A. Calzado, José M. Rojas, Giovanni Appendino, Eduardo Muñoz, José Alcamí

\section{To cite this version:}

Luis M. Bedoya, Nieves Márquez, Natalia Martínez, Silvia Gutiérrez-Eisman, Amparo Álvarez, et al.. SJ23B, a jatrophane diterpene activates classical pkcs and displays strong activity against HIV. Biochemical Pharmacology, 2009, 77 (6), pp.965. 10.1016/j.bcp.2008.11.025 . hal-00531847

\section{HAL Id: hal-00531847 https://hal.science/hal-00531847}

Submitted on 4 Nov 2010

HAL is a multi-disciplinary open access archive for the deposit and dissemination of scientific research documents, whether they are published or not. The documents may come from teaching and research institutions in France or abroad, or from public or private research centers.
L'archive ouverte pluridisciplinaire HAL, est destinée au dépôt et à la diffusion de documents scientifiques de niveau recherche, publiés ou non, émanant des établissements d'enseignement et de recherche français ou étrangers, des laboratoires publics ou privés. 


\section{Accepted Manuscript}

Title: SJ23B, a jatrophane diterpene activates classical pkcs and displays strong activity against HIV in vitro

Authors: Luis M. Bedoya, Nieves Márquez, Natalia Martínez, Silvia Gutiérrez-Eisman, Amparo Álvarez, Marco A. Calzado, José M. Rojas, Giovanni Appendino, Eduardo Muñoz, José Alcamí

PII: S0006-2952(08)00858-7

DOI: doi:10.1016/j.bcp.2008.11.025

Reference: BCP 10027

To appear in: $\quad B C P$

Received date: $\quad 29-9-2008$

Revised date: 24-11-2008

Accepted date: $\quad 25-11-2008$

Please cite this article as: Bedoya LM, Márquez N, Martínez N, Gutiérrez-Eisman S, Álvarez A, Calzado MA, Rojas JM, Appendino G, Muñoz E, Alcamí J, SJ23B, a jatrophane diterpene activates classical pkcs and displays strong activity against HIV in vitro, Biochemical Pharmacology (2008), doi:10.1016/j.bcp.2008.11.025

This is a PDF file of an unedited manuscript that has been accepted for publication. As a service to our customers we are providing this early version of the manuscript. The manuscript will undergo copyediting, typesetting, and review of the resulting proof before it is published in its final form. Please note that during the production process errors may be discovered which could affect the content, and all legal disclaimers that apply to the journal pertain. 


\section{Title page}

\section{SJ23B, A JATROPHANE DITERPENE ACTIVATES CLASSICAL PKCS AND DISPLAYS STRONG ACTIVITY AGAINST HIV IN VITRO.}

Luis M. Bedoya ${ }^{1}$, Nieves Márquez ${ }^{2}$, Natalia Martínez ${ }^{3}$, Silvia Gutiérrez-Eisman ${ }^{3}$, Amparo Álvarez ${ }^{1}$, Marco A. Calzado ${ }^{2}$, José M. Rojas ${ }^{3}$, Giovanni Appendino ${ }^{4}$, Eduardo Muñoz ${ }^{2}$, José Alcamí $^{1 \dagger}$

\footnotetext{
Affiliations

${ }^{1}$ Unidad de Inmunopatología del SIDA. Centro Nacional de Microbiología. Instituto de Salud Carlos III. 28220 Majadahonda. Spain

${ }^{2}$ Departamento de Biología Celular, Fisiología e Inmunología, Facultad de Medicina, Universidad de Córdoba, Avda. de Menendez Pidal s/n, 14004 Córdoba, Spain

${ }^{3}$ Unidad de Biología Celular. Centro Nacional de Microbiología. Instituto de Salud Carlos III. 28220 Majadahonda. Spain

${ }^{4}$ Dipartimento di Scienze Chimiche, Alimentari, Farmaceutiche e Farmacologiche, Università del Piemonte Orientale, Via Bovio 6, 28100 Novara, Italy

Running title: SJ23B a new inhibitor of HIV infection

${ }^{\sharp}$ Contact corresponding author: José Alcamí, Unidad de Inmunopatología del SIDA. Centro Nacional de Microbiología. Instituto de Salud Carlos III. Ctra. Majadahonda-Pozuelo, km. 2. 28220 Majadahonda. Madrid. Spain. Phone: 34.91.5097052; Fax: 34.91.5097919; E-mail: ppalcami@isciii.es
} 


\begin{abstract}
Existence of virus reservoirs makes the eradication of HIV infection extremely difficult. Current drug therapies neither eliminate these viral reservoirs nor prevent their formation. Consequently, new strategies are needed to target these reservoirs with the aim of decreasing their size. We analysed a series of jatrophane diterpenes isolated from Euphorbia hyberna and we found that one of them, SJ23B, induces the internalization of the HIV-1 receptors CD4, CXCR4 and CCR5 and prevents $\mathrm{R} 5$ and $\mathrm{X} 4$ viral infection in human primary $\mathrm{T}$ cells at the nanomolar range. Moreover, SJ23B is a potent antagonist of HIV-1 latency. Using Jurkat-LAT-GFP cells, a model for HIV-1 latency, we found that prostratin and SJ23B activate HIV-1 gene expression, with SJ23B being at least 10 -fold more potent than prostratin. SJ23B did not elicit transforming foci activity in NIH 3 T3 cells but is a potent activator of $\mathrm{PKC} \alpha$ and $\delta$ as measured by in vitro kinase assays and by cellular translocation experiments. By using isoform-specific PKC inhibitors we found that cPKCs are critical for SJ23B-induced HIV-1 reactivation. We also showed that both

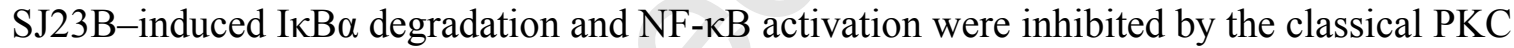
inhibitor, Gö6976. Accordingly, SJ23B synergizes with ionomycin to translocate PKC $\alpha$ to the plasma membrane and to activate the NF- $\kappa$ B pathway. Moreover, SJ23B activates both NF- $\mathrm{B}$ and Sp1-dependent transcriptional activities in primary $\mathrm{T}$ cells. We have shown that diterpene jatrophanes represent a new member of anti-AIDS agents that could be developed for mitigating HIV reactivation.
\end{abstract}

Keywords: HIV-1 and latency reactivation; SJ23B; Prostratin and phorbol esters; Receptors down-regulation; NF-kB and PKC pathways. 


\section{Introduction}

Highly active antiretroviral therapy (HAART) has shown to reduce viral load to undetectable levels and significantly decreased the death rate attributable to AIDS [1]. However, the persistence of HIV reservoirs, particularly in resting CD4+ T cells, is a major obstacle for HIV eradication [2]. Furthermore, these reservoirs are a permanent source of virus production and lead to a persistent low level ongoing replication despite HAART treatment [3]. The clearance kinetics of this latently-infected virus population remains unclear, but some conjectures suggest that eradication of latent reservoirs would require more than 70 years of suppressive therapy [4]. Moreover, patients are likely to experience drug related toxicity and may have to change therapy due to the emergence of drug resistant strains. For these reasons, the search for long-term treatment strategies for HIV-1 infection is one of the main goals of antiretroviral therapy research.

Immunoactivation therapy to reduce the latent pool of HIV by treatment with the anti-CD3 antibody OKT-3 alone or in combination with interleukin-2, substantially failed to significantly decrease the viral reservoir [5], and more recently the use of enzyme histone deacetylase inhibitors, such as valproic acid, has been proposed [6]. In addition, different small molecules including phorbol esters [7], ingenols [8] and 1,2-diacylglycerol analogs [9], can also reactivate HIV. Treatment with these molecules in combination with other antiretroviral drugs acting at different steps of the viral cycle has been suggested as a potential strategy to activate viral reservoirs and eradicate the pool of latently HIV-infected $\mathrm{CD}^{+} \mathrm{T}$ cells [10]. Non-tumorpromoting deoxyphorbol esters such are prostratin and 12-deoxyphorbol 13-phenylacetate have been directly evaluated for their ability to reactivate latent virus both in latently infected cell lines and in primary memory $\mathrm{T}$ cells from HIV infected patients $[7,11]$. Prostratin was identified as the anti-viral constituent of the Samoan plant Homalanthus nutans [12] and its antiviral effect is 
due to two different mechanisms. On one hand, prostratin reactivates HIV-1 latency "in vitro" by protein kinase $\mathrm{C}$ (PKC)-dependent NF- $\mathrm{kB}$ activation $[12,13]$, and on the other hand, downregulates the expression of the HIV-1 receptor CD4 and the co-receptors CXCR4 and CCR5, thus avoiding the new infection of CD4+ cells [14].

The PKC family of serine/threonine kinases plays a central role in mediating the signal transduction of extracellular stimuli, which result in the production of the second messenger 1,2diacyl-sn-glycerol (DAG). The PKC family is composed of 12 members that are classified into three major subfamilies. The classical PKCs (cPKCs: $\alpha, \beta_{\mathrm{I}}, \beta_{\mathrm{II}}$ and $\gamma$ ) are $\mathrm{Ca}^{2+}$ - and DAGdependent, whereas the novel PKCs (nPKCs: $\delta, \varepsilon, \eta$ and $\theta$ ) are $\mathrm{Ca}^{2+}$-independent but DAGresponsive. The atypical PKCs (aPKCs: $\zeta$ and $\lambda_{\mathfrak{l}}$ ) lack the responses to both $\mathrm{Ca}^{2+}$ and DAG [15]. A highly conserved cysteine-rich motif ( $\mathrm{C} 1$ domain) in the regulatory region of the PKCs acts as the specific receptor for the DAG signal [16]. The cPKCs and nPKCs have two tandem C1 domains in their $\mathrm{N}$-terminal domain, the $\mathrm{Cla}$ and $\mathrm{Clb}$ domains, which show high binding affinities in vitro for DAG, phorbol esters and other PKC activators such as Ingenol and bryostatin-1 $[17,18]$.

The translocation of PKCs from cytoplasm to plasma membrane and other subcellular localizations is the hallmark for PKC activation, and isozyme-specific functions may result in part from a different subcellular localization of activated PKC [19]. Several studies have shown that PKC translocation is isoform-, cell type-, and activator-specific [20, 21]. Therefore, distinct patterns of localization of PKC, and therefore of access to substrates, might underlie distinct biological responses to a given PKC ligand. Clearly, the identification of potent natural or synthetic PKC agonists lacking tumor-promoter activities has opened new research avenues for the treatment of HIV-1 latency. 
Jatrophane diterpenes isolated from Euphorbia hyberna L. (Irish spurge) [22] have previously shown activity as microtubule-interacting agents [23], but there are no data about its potential anti-HIV activity. In the present study we investigate the anti-HIV-1 effects of a series of jatrophane diterpenes and we have found that SJ23B is endowed with potent antiviral activity through down-regulation of HIV receptors and induction of viral reactivation.

\section{Material and methods}

\subsection{Reagents}

The jatrophane diterpenes were isolated from Euphorbia hyberna L. and Terracinolide C from Euphorbia dendroides L. as previously described [22, 24]. mAbs to CD3, CD4, CXCR4, CD69, HLA-A,B,C and CCR5 were supplied by Becton Dickinson (Mountain View, CA, USA). IL-2 was supplied by Chiron (Emeryville, CA. USA). The anti-IкB $\alpha$ mAb 10B was a gift from R. T. Hay (St. Andrews, Scotland) and the anti-tubulin mAb was purchased from Sigma Co (St. Louis, MO, USA). The inhibitor Rottlerin was obtained from Alexis Co (Lausanne, Switzerland) and the inhibitors Gö6983, Gö6976 and Gö6850 were from Calbiochem (EMD Biosciences, Inc. Darmstadt, Germany). $\left[\gamma_{-}{ }^{32} \mathrm{P}\right] \mathrm{ATP}(3000 \mathrm{Ci} / \mathrm{mmol})$ was from MP Biomedicals (Irvine, CA, USA). Prostratin was kindly provided by AIDS Research Alliance (Hollywood, CA, USA) or obtained from Alexis Co (San Diego, CA, USA). All other reagents were from Sigma-Aldrich.

\subsection{Cells}

MT-2 cells (American Type Culture Collection, Rockville, MD, USA) were cultured in RPMI 1640 medium containing 10\% (v/v) fetal bovine serum, $2 \mathrm{mM}$ L-glutamine, penicillin (50 $\mathrm{IU} / \mathrm{mL}$ ) and streptomycin (50 $\mu \mathrm{g} / \mathrm{mL})$ (all Whittaker M.A. Bio-Products, Walkerville, MD, 
USA). MT- 2 cells were cultured at $37^{\circ} \mathrm{C}$ in a $5 \% \mathrm{CO}_{2}$ humidified atmosphere. $293 \mathrm{~T}$ cells were cultured in DMEM medium containing 10\% (v/v) fetal bovine serum, $2 \mathrm{mM}$ L-glutamine, penicillin (50 IU/mL) and streptomycin (50 $\mu \mathrm{g} / \mathrm{mL})$ (Whittaker). 293T cells were cultured at 37 ${ }^{\circ} \mathrm{C}$ in a $5 \% \mathrm{CO}_{2}$ humidified atmosphere. Jurkat-LAT-GFP is a Jurkat derived clone latently infected with a recombinant virus containing the GFP gene driven by the HIV-LTR promoter [25]. The cells were stimulated with the indicated compounds for $6 \mathrm{~h}$ and the GFP expression was analysed by flow cytometry in an EPIC XL flow cytometer (Coulter, Hialeah, FL). Ten thousand gated events were collected per sample and the fluorescence pattern was determined.

\subsection{Mononuclear cell preparation}

PBMCs were isolated from healthy blood donors by centrifugation through a Ficoll-Hypaque gradient (Pharmacia Corporation, North Peapack, New Jersey) and were resuspended in RPMI 1640 medium supplemented with 10\% FCS (PAN Biotech GmbH, Aidenbach, Germany), 2 mM L-gutamine and antibiotics (100 $\mu \mathrm{g} / \mathrm{ml}$ streptomycin and $100 \mathrm{U} / \mathrm{ml}$ penicillin; Whithaker, USA) before culture at a concentration of $2 \times 10^{6}$ cells $/ \mathrm{ml}$. In some experiments, PBMCs were preactivated with anti-CD3 antibodies (1/1000 dilution; Becton Dickinson) and IL2 (300 IU/ml; Chiron) for 48 hours.

\subsection{Plasmids}

The vector pNL4.3-luc was generated by cloning the luciferase gene in the HIV-1 proviral clone pNL4.3 [26]. Plasmid pNL4.3-Renilla was generated cloning the renilla gene in the nef site of pNL4.3 [27] and pJR Renilla plasmid was generated cloning the env gene of HIV-1 JR $\mathrm{CSF}_{\text {in }}$ the pNL4.3-Renilla plasmid. The 3-enh-кB-ConA-luc plasmid [28] carries a luciferase gene under 
the control of three synthetic copies of the $\mathrm{\kappa B}$ consensus of the immunoglobulin $\kappa$-chain promoter cloned into the BamHI site located upstream from the conalbumin transcription start site. The SP1-luc plasmid (a kind gift from Dr Solís-Herruzo, Hospital 12 de Octubre, Madrid, Spain) contains two consensus sequences for SP1 cloned into the p19LUC vector. DNA for vesicular stomatitis virus (VSV) G glycoprotein was cloned in the pcDNA3.1 plasmid (pcDNAVSV) [29]. The plasmids pCEFL-KZ-HA and pCEFL-KZ-HA-K-Ras V12 were previously described [30].The pEGFP-N1 derived plasmids PKC $\alpha$-GFP and PKC 8 -GFP were obtained from Dr. P.M. Blumberg (NCI, MD, USA).

\subsection{Anti-HIV activity evaluation}

Classic antiviral assays were performed by pre treating PBMCs activated with CD3+IL2 with different concentrations of the compounds for two hours and infecting for 2 additional hours with HIV (NL4.3 strain) or recombinant HIV (NL4.3-Renilla). Afterwards, the cell culture was extensively washed with PBS, compounds were added again and left in culture for 48 hours. Supernatants were collected and HIV p24 antigen was measured using an enzyme-like immunoassay for antigen p24 detection (Innotest ${ }^{\mathrm{TM}} \mathrm{HIV}$ Ag mAb; Innogenetics, Barcelona, Spain). Viral production in control untreated test was at least $10 \mathrm{ng} \mathrm{p} 24 / \mathrm{ml}$ (threshold of the test was $10 \mathrm{pg} \mathrm{p} 24 / \mathrm{ml})$. The recombinant virus assay was performed as follows: Infectious supernatants were obtained from calcium phosphate transfection on 293T cells of plasmids pNL4.3-Renilla, pJR-Renilla and cotransfection of the pNL4.3-Luc-R $E^{-}$(AIDS Research and Reference Reagent program, NIAID, National Institutes of Health, MD, USA), full length HIV DNA not expressing HIV envelope, and pcDNA-VSV, that express G protein of Vesicular Stomatitis Virus (VSV). These supernatants were used to infect cells, previously treated with the 
compounds to be evaluated for 2 hours. Anti HIV activity quantification was performed 48 or 96 hours post-infection, depending on the experiment. Briefly, cells were lysed following the manufacturer instructions provided by "Renilla luciferase assay system" (Promega, Madison, WI). Relative luminescence units (RLUs) were obtained in a luminometer (Berthold Detection Systems, Pforzheim, Germany) after the addition of substrate to cells extracts. Viability was performed in cells treated in parallel and in long term cultures with similar concentrations of compound to those used in the RV assay. Cell viability was evaluated with CellTiter Glo (Promega, Madison, WI) assay system following the Manufacturer's specifications or by propidium iodide addition and evaluation by flow cytometry (described below). Apoptosis was evaluated with Anexin V-FITC apoptosis detection kit (BD Pharmingen, Belgium) following the manufacturer recommendations. Inhibitory Concentrations $50\left(\mathrm{IC}_{50}\right)$ and Cytotoxic concentrations $50\left(\mathrm{CC}_{50}\right)$ were calculated using GraphPad Prism Software (sigmoidal doseresponse formula).

\subsection{Transfection assays}

Resting PBMCs were resuspended in $350 \mu 1$ of RPMI without supplements and electroporated using an Easyject plus Electroporator (Equibio, Middlesex, U.K.). PBMCs were transfected at $320 \mathrm{~V}, 1500 \mu \mathrm{F}$, and maximum resistance with the plasmids at a concentration of $0.5 \mu \mathrm{g} / 10^{6}$ cells. After transfection, cells were incubated in complete RPMI at $37^{\circ} \mathrm{C}$, activated or not with different stimuli and harvested 20 hours later. Luciferase activity (RLU) was measured in a luminometer following the Manufacturer's instructions provided by “Luciferase Assay System Kit with Reporter Lysis Buffer” (Promega, Madison, WI, USA).

\subsection{CD4, CCR5, CXCR4, CD69 and HLA-1 detection by Flow cytometry}


Single-, double- or three-color immunophenotyping was performed with a FACScalibur flow cytometer (Becton Dickinson, Belgium). Background staining was assessed with the appropriate isotype- and fluorochrome-matched control $\mathrm{mAb}$ and subtracted. Results are shown as percentage of cells expressing the receptor or by receptor mean intensity (MI). PBMCs resting or preactivated with anti-human-CD3 (dilution 1/1000) and IL-2 (300 IU/ml) for 48 hours were analysed using forward-versus-side scatter dot plots.

\subsection{Western blots}

Jurkat-LAT-GFP cells $\left(10^{6} \mathrm{cell} / \mathrm{s} / \mathrm{ml}\right)$ were stimulated with the indicated compounds. Cells were then washed with PBS and proteins extracted in $50 \mu$ of lysis buffer (20 mM Hepes pH 8.0, 10 mM KCl, $0.15 \mathrm{mM}$ EGTA, $0.15 \mathrm{mM}$ EDTA, $0.5 \mathrm{mM} \mathrm{Na}_{3} \mathrm{VO}_{4}, 5 \mathrm{mM} \mathrm{NaFl}, 1 \mathrm{mM}$ DTT, leupeptin $1 \mu \mathrm{g} / \mathrm{ml}$, pepstatin $0.5 \mu \mathrm{g} / \mathrm{ml}$, aprotinin $0.5 \mu \mathrm{g} / \mathrm{ml}$, and $1 \mathrm{mM} \mathrm{PMSF}$ ) containing $0.5 \%$ NP-40. Protein concentration was determined by the Bradford assay (Bio-Rad, Richmond, CA, USA) and thirty $\mu \mathrm{g}$ of proteins were boiled in Laemmli buffer and electrophoresed in $10 \%$ SDS/polyacrylamide gels. Separated proteins were transferred to nitrocellulose membranes ( $0.5 \mathrm{~A}$ at $100 \mathrm{~V} ; 4^{\circ} \mathrm{C}$ ) for $1 \mathrm{~h}$. Blots were blocked in TBS solution containing $0.1 \%$ Tween 20 and $5 \%$ non-fat dry milk overnight at $4{ }^{\circ} \mathrm{C}$, and immunodetection of specific proteins was carried out with primary antibodies using an ECL system (GE Healthcare, Uppsala, Sweden).

\subsection{Isolation of nuclear extracts and mobility shift assays}

Jurkat-LAT-GFP cells $\left(10^{6} / \mathrm{ml}\right)$ were stimulated with the agonists in complete medium as indicated. Cells were then washed twice with cold PBS and nuclear proteins isolated by standard procedures [31]. Protein concentration was determined by the Bradford method. For the 
electrophoretic mobility shift assay (EMSA), the consensus oligonucleotide probe NF-kB, 5'AGTTGAGG-GGACTTTCCCAGG-3' was end-labelled with $\left[\gamma_{-}{ }^{32} \mathrm{P}\right]$ ATP. The binding reaction mixture contained $3 \mu \mathrm{g}$ of nuclear extract, $0.5 \mu \mathrm{g}$ poly(dI-dC) (GE Healthcare, Uppsala, Sweden), $20 \mathrm{mM}$ Hepes pH 7, $70 \mathrm{mM} \mathrm{NaCl}, 2 \mathrm{mM}$ DTT, 0.01\% NP-40, $100 \mu \mathrm{g} / \mathrm{ml} \mathrm{BSA,} \mathrm{4 \%} \mathrm{Ficoll,} \mathrm{and}$ $100000 \mathrm{cpm}$ of end-labelled DNA fragments in a total volume of $20 \mu \mathrm{l}$. After 30 min incubation at $4{ }^{\circ} \mathrm{C}$, the mixture was electrophoresed through a native $6 \%$ polyacrylamide gel containing $89 \mathrm{mM}$ Tris-borate, $89 \mathrm{mM}$ boric acid and $1 \mathrm{mM}$ EDTA. Gels were pre-electrophoresed for $30 \mathrm{~min}$ at 225 $\mathrm{V}$ and then for $2 \mathrm{~h}$ after loading the samples. These gels were dried and exposed to X-Ray film at $80{ }^{\circ} \mathrm{C}$.

\subsection{Expression of PKCs-GFP in cultured cells and visualization by confocal} microscopy

CHO-K1 cells were grown on $12 \mathrm{~mm}$ round coverslips to $50-75 \%$ confluence. Transient transfection was conducted using Jet Pei reagent (Polyplus transfection, France), following the Manufacturer's instructions. Fluorescence became detectable $24 \mathrm{~h}$ after transfection, and all experiments were performed 3 days after transfection. Prior to observation, transiently transfected CHO-K1 cells were washed twice with PBS containing $1 \%$ FCS prewarmed to $37^{\circ} \mathrm{C}$. All PKC activators were diluted to specified concentrations in the same medium, and the final concentration of solvent (DMSO) was always less than 1\%. After 10 min of treatment the cells were fixed and analysed with a confocal microscopy (Espectral TCS-SP2-AOBS, Leica).

\subsection{Transformation assays}


NIH 3 T3 fibroblasts were maintained in medium DMEM supplemented with $10 \%$ calf serum and treated either with SJ23B, prostratin, or PMA. All compounds were used at $0.1 \mu \mathrm{M}$ concentration. As positive control, K-Ras V12 (pCEFL-KZ-HA-K-Ras V12) was transfected by the calcium phosphate precipitation technique. Morphologically transformed foci were scored after 2-3 weeks in culture [30]. As negative control, vector pCEFL-KZ-HA was transfected under similar conditions.

\subsection{PKC Kinase assay}

In vitro activation of recombinant PKC $\alpha$ and $\delta$ (Invitrogen, Paisley, UK) was assayed by measuring the incorporation of $\mathrm{P}^{32}$ from $\left(\gamma^{32} \mathrm{P} 6000 \mathrm{Ci} / \mathrm{mmol}\right)$ ATP (Perkin Elmer, MA, USA) into the specific PKC substrate peptide [QKRPSQRSKYL]. PKC activation was measured using the PKC Assay Kit (Millipore, MA, USA) following the instructions of the manufacturer. SJ23B or PMA were added at the indicated concentrations from the appropriated DMSO stocks, the final concentration of the diluents not exceeding $0.2 \%$. The assay tubes were incubated $10 \mathrm{~min}$ at $30{ }^{\circ} \mathrm{C}$ and the reaction was stopped by chilling on ice. Aliquots of $25 \mu 1$ were spotted onto P81 phosphocellulose papers followed by washing three times in $0.5 \%$ phosphoric acid and once with acetone. The filters were transferred to scintillation vials and the bound radioactivity was read in a scintillation counter. In every single experiment, each ligand concentration was assayed in triplicate and a dose-response curve was plotted.

\section{Results}

\subsection{SJ23B inhibits "in vitro" infection of HIV in MT-2 cells and PBMCs}

SJ23B presents a different chemical structure to those of phorbol esters and prostratin, although some structural correlations exist (Figure 1). Prostratin lacks a carbon chain at position $\mathrm{C}_{12}$ that 
makes it functionally distinct from PMA, a typical phorbol ester. This feature could explain why prostratin is not a tumour promoter, but rather protects cells from tumours induced by PMA [32]. Computer modeling analysis suggests that SJ23B lacking lipophilic chains could bind PKC, and therefore we were interested in investigating its anti-HIV-1 activity. MT-2 cells were infected with an X4 tropic recombinant virus (NL4.3-Renilla) carrying the renilla-luciferase reporter gene in the presence of different concentrations of compound. As observed in Figure 2A, when SJ23B was added to cultures two hours before infection, strong inhibition of viral replication was observed in MT-2 cells, at nanomolar concentrations, with $\mathrm{IC}_{50}$ values of about $2 \mathrm{nM}$. When activated PBMCs were infected under the same conditions, strong inhibition of viral replication was also obtained, with $\mathrm{IC}_{50}$ values near $20 \mathrm{nM}$. Cell death was not observed at concentrations lower than $10 \mu \mathrm{M}$ and CC50 was above $100 \mu \mathrm{M}$ in both PBMCs and MT-2 cells (Figure 2A). To further evaluate SJ23B toxicity, a long term viability assay (2 weeks) was performed, and cell viability and apoptosis were determined at different times along treatment (Figure 2C). No toxicity was detected during treatment, and apoptosis was only barely induced as compared to a non-treated control of PBMCs, ruling out the potential toxicity of long term treatments in human cells. Similar results were obtained with non preactivated resting PBMCs (Data not shown). To corroborate the anti-HIV activity, a classical p24 detection antiviral assay infecting activated PBMCs with either wild type HIV (NL4.3) or a recombinant virus (NL4-3-Renilla) was performed. As shown in Figure 2B, SJ23B is able to inhibit p24 production with similar $\mathrm{IC}_{50}$

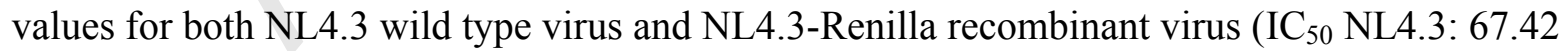
$\mathrm{nM}$; $\mathrm{IC}_{50}$ NL4.3-Renilla: $\left.76.86 \mathrm{nM}\right)$. Moreover, these $\mathrm{IC}_{50}$ values are close to the $\mathrm{IC}_{50}$ obtained for PBMCs in the recombinant virus assay.

To compare the antiviral potency of SJ23B and prostratin, replication of X4 and R5 HIV strains was evaluated in activated PBMCs. Infections were performed with recombinant viruses (RV) in 
which renilla-luciferase reporter gene had been cloned. As depicted in Figure 3, inhibition of HIV infection by SJ23B is at least ten fold more potent than that of prostratin and this activity was found for infections with both, X4 and R5 tropic viruses.

\subsection{SJ23B decreases expression of HIV receptors CD4, CCR5 and CXCR4 in PBMCs}

Early stage of the HIV cycle involves the study of viral entry as one of the most suspicious steps of drug interference. To investigate this possibility, the expression of cell surface receptors involved in HIV entry was measured. After activation of PBMCs with anti-CD3 and IL-2 for 48 hours, cells were stimulated with PMA or SJ23B and left in culture for 2, 5, 24 and 48 hours. SJ23B downregulates CD4, CXCR4 and CCR5 expression in a concentration-dependent manner, with the same pattern of down regulation as PMA. Results are shown as receptor mean intensity and percentage of expression. (Figure 4A). To rule out a non-specific effect of SJ23B on cell receptors, CD69 and HLA-1 expression in resting PBMCs was measured. PBMCs were stimulated with PMA or SJ23B and left in culture for 2, 5, 24 and 48 hours. CD69 expression was strongly enhanced by both compounds, while HLA-1 expression was not modified. Results are shown as receptor mean intensity (Figure 4B).

\subsection{Antiviral effect of SJ23B is due to down-regulation of HIV receptors}

To confirm that receptor expression was the only mechanism involved in HIV inhibition by SJ23B, activated PBMCs were stimulated with PMA $(0.04 \mu \mathrm{M})$ or SJ23B $(0.1$ and $1 \mu \mathrm{M})$, and five hours later, when strong CD4, CCR5 and CXCR4 down-regulation was obtained, cells were infected overnight with either R5, X4 HIV tropic strains or a VSV-pseudotyped viral clone lacking the HIV envelope that enters into the cell regardless of HIV receptors. Receptors expression was measured at different times during treatment $(0,4$ and 7 days) and infection was 
measured at day 4. As shown in Figure 5B, infection of PBMCs with R5 and X4 tropic HIV strains was inhibited by SJ23B and PMA-after 4 days. Inhibition of viral replication correlated with the capacity of SJ23B to down-regulate receptors (Figure 5A). Infection of PBMCs with VSV pseudotyped virus was not inhibited by SJ23B or PMA as expected, since these viruses enter host cells by a receptor independent mechanism. Moreover, SJ23B produces an enhancement of the infectivity of pseudotyped viruses at 0.1 and $1 \mu \mathrm{M}$ doses (Figure 5B), suggesting a transcriptional promoting activity similar to that previously reported for prostratin or PMA.

\subsection{SJ23B activates PKC and induces HIV replication through a classical PKC pathway}

The very low number of latently HIV-infected cells in vivo makes purification and biochemical analysis of these cells impractical. As an experimentally tractable and relevant model of postintegration HIV latency, we have employed the Jurkat-LAT-GFP clone to explore the impact of SJ23B on HIV latency. Jurkat-LAT-GFP cells contain a single, integrated lentiviral vector genome expressing GFP under the control of the HIV-1 LTR. This allows rapid assessment of HIV transcriptional activity by cytometric detection of GFP epifluorescence [25]. Thus, JurkatLAT-GFP cells were treated with increasing concentrations of SJ23B or prostratin and we found that $\mathrm{SJ} 23 \mathrm{~B}\left(\mathrm{IC}_{50}\right.$ around $\left.50 \mathrm{nM}\right)$ is at least ten times more potent than prostratin $\left(\mathrm{IC}_{50}\right.$ around 0.5 $\mu \mathrm{M})$ to induce HIV-1 reactivation from latency (Figure 6A). To further assess the PKC dependence of SJ23B-mediated antagonism of HIV latency, we pretreated Jurkat-LAT-GFP cells with control medium or the chemical inhibitors Gö6976 (classical PKCs inhibitor), Gö6850 (classical and novel PKCs inhibitor), Gö6983 (pan-PKC inhibitor) and Rottlerin (PKC $\delta$ inhibitor) at the indicated concentrations. Gö6976, Gö6850 and Gö6983 strongly inhibited GFP expression induced by SJ23B, further implicating a PKC-dependent signalling step in this response. In 
contrast, the PKC $\delta$ inhibitor Rottlerin did not affect phorbol-induced GFP expression, ruling out the involvement of this PKC in HIV-1 reactivation, at least in Jurkat-LAT-GFP cells (Figure 6B). Next, we analysed the ability of SJ23B to activate kinase activity in vitro using a substrate peptide that can be efficiently phosphorylated both by PKC $\alpha$ and PKC $\delta$. We show that SJ23B activates both PKC isoenzymes in a concentration-dependent manner although it was more potent for $\mathrm{PKC} \alpha$ activation compared to $\mathrm{PKC} \delta$ (Figure 6C).

\subsection{SJ23B activates NF- $\mathrm{KB}$ through a classical PKC dependent pathway}

Since prostratin and other PKC agonists antagonise HIV-1 latency by activating the canonical pathway for NF-kB activation, we explored the signalling pathway activated by SJ23B in JurkatLAT-GFP cells that mediates activation of the latent HIV proviruses. The cells were stimulated with SJ23B $(1 \mu \mathrm{M})$ in the absence or presence of the indicated PKC inhibitors, and degradation

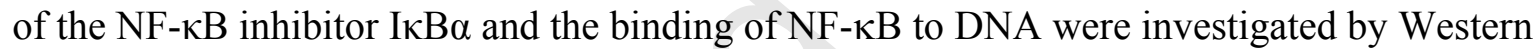
Blots and gel retardation assays respectively. We found that SJ23B induced the degradation of I $\kappa \mathrm{B} \alpha$ and the binding of NF- $\mathrm{KB}$ to DNA and both activities were completely inhibited by the presence of classical PKCs inhibitors (Fig. 7). As expected, Rottlerin did not affect either SJ23B-

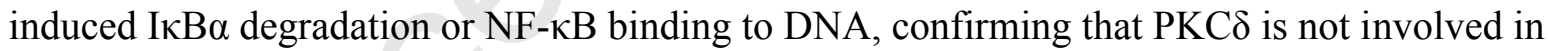
the HIV-1 antagonizing activity of SJ23B.

The translocation of PKC from the cytoplasm to subcellular localizations is the hallmark for PKC activation [33], and their isozyme-specific functions may result in part from differences in subcellular localization [20]. The classical PKCs are $\mathrm{Ca}^{2+}$ - and DAG-dependent and we hypothesized whether SJ23B could synergise with increased intracellular calcium levels in the 
cellular redistribution of PKC $\alpha$. In order to explore the specificity of PKC $\alpha$ translocation in response to PMA and SJ23B in the absence or presence of the calcium ionophore ionomycin, CHO-K1 cells were transiently transfected with a construct containing the full length open ready frame of PKCa fused to the GFP gene. In the absence of stimuli, PKCa was scattered in the cytoplasm and after PMA treatment the protein was mainly translocated to the plasma membrane. SJ23B also induced redistribution of the PKC $\alpha$ to the plasma membrane that was further enhanced by the presence of ionomycin $(0.5 \mu \mathrm{M})$ (Figure $8 \mathrm{~A})$. Conversely, SJ23B alone or in combination with ionomycin did not induce $\mathrm{PKC} \delta$ translocation to the plasma membrane (data not shown).

To correlate the effects of SJ23B in the translocation of PKC $\alpha$ in $\mathrm{CHO}$ cells with the NF-kB activity in Jurkat-LAT-GFP cells, we treated this cell line with increasing concentration of SJ23B in the absence or presence of ionomicyn $(0.5 \mu \mathrm{M})$ and the binding of NF- $-\mathrm{KB}$ to DNA was analysed by electrophoretic mobility shift assays. In Figure 8B it is shown that elevated intracellular levels cooperate with SJ23B to increase the DNA binding activity of NF- $\mathrm{kB}$. Altogether our results indicate that the major pathway for SJ23B to antagonize HIV-1 latency involves the activation of $\mathrm{PKC} \alpha$, which in turn activates the canonical NF- $\mathrm{KB}$ pathway.

\subsection{SJ23B do not induce cell transformation}

There is a general agreement that only phorbol esters inducing a sustained PKC translocation to the cell membrane are endowed with tumour promoter activity. To demonstrate that SJ23B lacks tumour promoter activity we performed transforming cell assays in NIH 3T3 fibroblasts [34], and we found that both SJ23B and prostratin were unable to elicit transforming foci, while treatment 
with PMA to the same concentrations, or transfection with KrasV12, strongly induced cell transformation (Figure 9).

\subsection{SJ23B activates HIV-1 transcription and induces NF-кB- and Sp1-dependent gene expression in peripheral blood mononuclear cells}

To further assess the effect of SJ23B in HIV-1 transcriptional activation in primary cells, a fulllength HIV-DNA plasmid containing the luciferase gene instead of nef (pNL4.3-Luc) was transfected into resting PBMCs. In Figure 10 it is shown that luciferase activity reflecting HIV reactivation was induced when treated with PMA and two different doses of SJ23B. Prostratin induces luciferase activity at $1 \mu \mathrm{M}$, but not at $0.1 \mu \mathrm{M}$. Different regulatory sequences could also be implicated in SJ23B-induced HIV reactivation. To further analyze the transactivation mechanism, luciferase expression vectors under the control of three tandem $\kappa \mathrm{B}$ consensus repeats (3-enhancer-кB-ConA-Luc) or Sp1 were transfected into PBMCs and luciferase activity was measured after 20 hours (Figure 10). Induction of the luciferase gene under the control of three $\kappa \mathrm{B}$ consensus repeats was observed when cells were activated with $\mathrm{SJ} 23 \mathrm{~B}$, at higher levels than prostratin-induced stimulation. Also, SJ23B seems to induce activation of SP1 (Sp1-Luc) similarly to prostratin. Finally, transactivation of NFAT transcription factor was not detected when PBMCs were stimulated with SJ23B or prostratin (data not shown). Therefore, SJ23B seems to be a more effective promoter transactivator than prostratin in primary cells mainly through activation of NF- $\mathrm{KB}$.

3.8. Acetylation at position $\mathrm{C}-16$ is required for the $\mathrm{HIV}-1$ latency antagonizing activity of jatrophane diterpenes 
A series of jatrophane diterpenes were also tested on Jurkat-LAT-GFP cells for comparison with SJ23B. Jatrophane polyesters are highly functionalized, and occur as complex mixtures. They are therefore difficult to obtain in amounts sufficient to sustain a systematic structure-activity study. Nevertheless, comparison of a series of jatrophanes available by isolation from two Mediterranean spurges (E. hyberna and E. dendroides) shows that acetylation of the 15-hydroxyl and acetoxylation at C-2 are critical for the HIV-1 latency antagonising activity. Both modifications are relatively redundant for inhibition of P-glycoprotein, the only molecular target so far identified for this type of compounds [24]. This observation is non surprising since, given the wide diversity of functional groups present in this type of compounds, countless possibilities of specific interaction with a macromolecular target can exist (Figure 11).

\section{Discusion}

AIDS continues to be a global health threat, although new therapies, especially the highly active antiretroviral therapy (HAART), have reduced dramatically the death rate attributable to HIV infections. However, HAART associated problems such as resistance emergence and drug toxicity, makes the eradication of the virus essential in order to end long term treatments, currently sustained for life. This imperative objective can only be achieved by eradicating HIV reservoirs completely from infected patients.

The identification of potent natural or synthetic PKC agonists lacking tumour-promoter and cellular proliferative activities has opened new research avenues for the treatment of cancer and HIV-1 latency. Bryostatin-1 has been shown to regulate protein kinase $\mathrm{C}$ (PKC) activity and can potentially inhibit tumour invasion, angiogenesis, cell adhesion, and limit the development of multidrug resistance [35]. Preclinical studies of bryostatin-1 have demonstrated both in vitro and in vivo anti tumour activity [36]. On the other hand, the capacity of prostratin to behave as an in 
vivo agent to purge latent HIV-1 proviruses has raised considerable interest, owing to a potential clinical application in combination with HAART to eradicate HIV-1 infection [37]. However, relatively high concentrations of prostratin are required to reactivate HIV-1 latency and it has been suggested that prostratin may have negative side effects and therefore it is unlikely that high-doses or long term treatment would be well tolerated [38]. In this study we analysed a series of natural jatrophane diterpenes derivatives and explored the mechanism by which these compounds antagonized HIV-1 latency. The strong anti-HIV activity at the nanomolar range was due to downregulation of HIV-1 receptors. Furthermore, we show that SJ23B can reactivate HIV1 from latency and could potentially contribute to a decrease in viral reservoirs. Therefore, similar to prostratin, SJ23B can qualify for the treatment of HIV-1 latency.

SJ23B is a diterpene with a jatrophane skeleton and a lactone moiety that was isolated from Euphorbia hyberna [22], a Mediterranean plant specimen without previous established antiviral activity. Although its chemical structure is quite different from phorbol esters, some biological correlations are possible, as our data indicate that SJ23B antagonizes HIV-1 latency through activation of classical PKCs in HIV-1 latently infected Jurkat cells. We do not yet know how SJ23B interacts with the phorbol binding domain of PKC, but the lack of lipophilic chains made this compound a potent PKC activator that does not allow a sustained translocation of cPKCs and nPKCs to the plasma membrane (data not shown). Thus, SJ23B is likely to belong to the class of PKC activators lacking tumour promoter activity that was confirmed on the transforming foci assays.

As previously described, prostratin enhanced $\mathrm{SP} 1$ and $\mathrm{NF}-\mathrm{\kappa B}$ pathway dependent transcription through a mechanism dependent on protein kinase $\mathrm{C}(\mathrm{PKC})$ [13]. To analyze transactivator activity of SJ23B in primary cells, resting PBMCs were transfected with a full length HIV clone driving the expression of luciferase as a reporter gene. Induction of HIV transcription by SJ23B 
was observed even at $0.1 \mu \mathrm{M}$, whereas higher doses of prostratin $(1 \mu \mathrm{M})$ were required to induce HIV expression. To further study the effect on HIV promoter, capability to induce transactivation of SJ23B, prostratin and PMA were studied with a luciferase expression vector under the control of consensus sequences for NF- $\mathrm{KB}$ and SP1. Results showed that SJ23B induces a clear

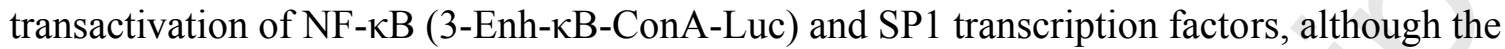
former was strongly induced. Altogether our results demonstrate that, similarly to prostratin, SJ23B targets the NF- $\mathrm{BB}$ and SP-1 transcription factors and is a potent activator of HIV-1 gene transcription in both primary cells and in HIV-1 latently infected cell lines, with SJ23B being at least 10 -fold more potent than prostratin.

We show here that SJ23B inhibits in vitro recombinant HIV (NL4.3-Renilla) infections of a lymphocyte cell line (MT-2) at the nanomolar range, leading us to test it in a more physiological system. Activated PBMCs infection experiments with recombinant viruses and classical HIVp24-gag antigen assays, corroborate the antiviral activity of SJ23B, lacking cell toxicity, since $\mathrm{CC}_{50}$ was not reached even at $100 \mu \mathrm{M}$. Thus, the interest of this compound as a potential antiHIV agent is based on its powerful activity, since it shows a high specificity index, greater than those obtained with similar cell lines and viral strains for AZT [39].

Data from preliminary assays implies that SJ23B does not display virucidal activity (data not shown) and its target should be previous to retrotranscription, suggesting a direct interference of SJ23B on viral entry. This process is mediated by viral glycoproteins and host cell receptors CD4, CXCR4 and/or CCR5. Expression of these receptors in cell surface is variable and particularly CXCR4 expression on the surface of PBMCs is low when freshly isolated, increasing to near $90 \%$ when maintained at least 12 hours without stimuli [40]. The effect of SJ23B on cell surface receptors was studied using PMA as reference compound. Results showed that SJ23B down-regulates CD4, CXCR4 and CCR5 receptors in preactivated PBMCs. This down-regulation 
should be associated with an inhibition of HIV infection by even R5 or X4 tropic viruses. Therefore, an RV assay is performed infecting PBMCs with X4 or R5 tropic viruses. As expected, SJ23B inhibits HIV replication in infections with both tropic viruses. These experiments suggest that antiviral activity of SJ23B is due to internalization of receptors. In summary, the persistence of latent reservoirs of human immunodeficiency virus type 1 (HIV1) represents a major barrier to virus eradication in patients treated with highly active antiretroviral therapy. Immunoactivation therapy to reduce the latent pool of HIV-1 substantially failed to significantly decrease the viral reservoir and the clinical results using histone deacetylase (HDAC) inhibitors such as valproic acid are controversial [10]. Therefore, the identification of potent natural or synthetic PKC agonists lacking tumour -promoter and cellular proliferative activities has opened new research avenues for the treatment of HIV-1 latency in combination with HAART. Similarly to others groups, we have shown that prostratin, a nontumour promoter phorbol ester, is a promising lead compound to antagonize HIV-1 latency, but the relatively high concentrations required for this activity may hamper its clinical use. In this report we identify a natural jatrophane diterpene isolated from Euphorbia hyberna, SJ23B, which is at least one order of magnitude more potent than prostratin. SJ23B induces the internalization of the HIV-1 receptors CD4, CXCR4 and CCR5 and prevents de novo viral infection in human primary $\mathrm{T}$ cells at the nanomolar range. Moreover, $\mathrm{SJ} 23 \mathrm{~B}$ activates $\mathrm{PKC}$ and like prostratin is a non-tumorogenic compound able to activate cells where HIV is "hidden" as latent provirus. Due to their mechanisms of action, it has been proposed that short cycles of treatment with these small molecules inducing HIV reactivation combined with HAART, could contribute to a decrease of viral reservoirs. This strategy has several advantages: first, potential immunosuppression due to down regulation of CD4 and chemokine receptors will be transient and restricted to few days. Second, burst of HIV replication induced by SJ23B would be controlled not only by the action of 
1

2

other antiretrovirals but by SJ23B on its own. Indeed, down regulation of HIV receptors by SJ23B would contribute to inhibition of viral spread and infection of new cells. This compound therefore represents an interesting lead for the development of new anti-AIDS drugs that could be exploited as adjuvant therapy to target latent reservoirs for patients on HAART. 


\section{ACKNOWLEDGEMENTS}

This work was supported by Ministerio de Ciencia y Tecnología (SAF2006-04247, SAF2004-04258 and SAF0037-C04-01), Ministerio de Sanidad y Consumo (ISCIII-INTRAMURAL 03/ESP27, PI0500017 and ISCIII-RETIC RD06/0020), Fondo de Investigación Sanitaria (FIS-040614 and PI040526), Fundación para la Investigación y la Prevención del Sida (FIPSE-36584), the Junta de Andalucía (P06-CTS-01353) and by the Spanish RIS Network "Red de Investigación en SIDA" (RD06-0006). We thank Centro de Transfusión de la Comunidad de Madrid for the supply of Buffycoats. Prostratin was a generous gift from the AIDS Research Alliance (ARA). Finally, we thank Ms. Carmen Cabrero-Doncel for her assistance with the manuscript. L.M.B. and N.M. contributes equally to the work.

Abbreviations used: PKC: Protein kinase C; HIV-1: Human immunodeficiency Virus-1; PMA: Phorbol Myristate Acetate; HAART: Highly active antiretroviral therapy; DAG: 2-diacyl-snglycerol.

ADDITIONAL FOOTNOTES. L.M.B. and N.M. contributed equally to the work 


\section{REFERENCES}

[1] Yeni PG, Hammer SM, Hirsch MS, Saag MS, Schechter M, Carpenter CC, et al. Treatment for adult HIV infection: 2004 recommendations of the International AIDS Society-USA Panel. JAMA 2004; 292:251-65.

[2] Alexaki A, Liu Y, Wigdahl B. Cellular reservoirs of HIV-1 and their role in viral persistence. Curr HIV Res. 2008; 6(5):388-400.

[3] Shen L, Siliciano RF. Viral reservoirs, residual viremia, and the potential of highly active antiretroviral therapy to eradicate HIV infection. J Allergy Clin Immunol 2008; 122(1):22-8.

[4] Strain MC, Little SJ, Daar ES, Havlir DV, Gunthard HF, Lam RY, et al. Effect of treatment, during primary infection, on establishment and clearance of cellular reservoirs of HIV-1. J Infect Dis $2005 ; 191: 1410-8$.

[5] Fraser C, Ferguson NM, Ghani AC, Prins JM, Lange JM, Goudsmit J, et al. Reduction of the HIV-1-infected T-cell reservoir by immune activation treatment is dose-dependent and restricted by the potency of antiretroviral drugs. AIDS 2000; 14:659-69.

[6] Lehrman G, Hogue IB, Palmer S, Jennings C, Spina CA, Wiegand A, et al. Depletion of latent HIV-1 infection in vivo: a proof-of-concept study. Lancet 2005; 366:549-55. 
[7] Kulkosky J, Culnan DM, Roman J, Dornadula G, Schnell M, Boyd MR, et al. Prostratin: activation of latent HIV-1 expression suggests a potential inductive adjuvant therapy for HAART. Blood 2001; 98:3006-15.

[8] Warrilow D, Gardner J, Darnell GA, Suhrbier A, Harrich D. HIV type 1 inhibition by protein kinase C modulatory compounds. AIDS Res Hum Retroviruses 2006; 22:854-64.

[9] Hamer DH, Bocklandt S, McHugh L, Chun TW, Blumberg PM, Sigano DM, et al. Rational design of drugs that induce human immunodeficiency virus replication. J Virol 2003; 77:1022736.

[10] Kulkosky J, Bray S. HAART-persistent HIV-1 latent reservoirs: their origin, mechanisms of stability and potential strategies for eradication. Curr HIV Res 2006; 4:199-208.

[11] Bocklandt S, Blumberg PM, Hamer DH. Activation of latent HIV-1 expression by the potent anti-tumor promoter 12-deoxyphorbol 13-phenylacetate. Antiviral Res 2003; 59:89-98.

[12] Gustafson KR, Cardellina JH 2nd, McMahon JB, Gulakowski RJ, Ishitoya J, Szallasi Z et al. A nonpromoting phorbol from the samoan medicinal plant Homalanthus nutans inhibits cell killing by HIV-1. J Med Chem 1992; 35:1978-86.

[13] Trushin SA, Bren GD, Asin S, Pennington KN, Paya CV, Badley AD. Human immunodeficiency virus reactivation by phorbol esters or T-cell receptor ligation requires both PKCalpha and PKCtheta. J Virol 2005; 79:9821-30. 
[14] Rullas J, Bermejo M, Garcia-Perez J, Beltan M, Gonzalez N, Hezareh M, et al. Prostratin induces HIV activation and downregulates HIV receptors in peripheral blood lymphocytes. Antivir Ther 2004; 4:545-54.

[15] Newton AC. Protein kinase C: structural and spatial regulation by phosphorylation, cofactors, and macromolecular interactions Chem Rev 2001; 101:2353-64.

[16] Colón-González F, Kazanietz MG. C1 domains exposed: from diacylglycerol binding to protein-protein interactions. Biochim Biophys Acta 2006; 1761:827-37.

[17] Slater SJ, Ho C, Kelly MB, Larkin JD, Taddeo FJ, Yeager MD, et al. Protein kinase Calpha contains two activator binding sites that bind phorbol esters and diacylglycerols with opposite affinities J Biol Chem 1996; 271:4627-31.

[18] Slater SJ, Taddeo FJ, Mazurek A, Stagliano BA, Milano SK, Kelly MB, et al. Inhibition of membrane lipid-independent protein kinase Calpha activity by phorbol esters, diacylglycerols, and bryostatin-1. J Biol Chem 1998; 273:23160-8.

[19] Shirai Y, Kashiwagi K, Yagi K, Sakai N, Saito N. Distinct effects of fatty acids on translocation of gamma- and epsilon-subspecies of protein kinase C. J Cell Biol 1998; 143:51121. 
[20] Wang QJ, Fang TW, Fenick D, Garfield S, Bienfait B, Marquez VE, et al. The lipophilicity of phorbol esters as a critical factor in determining the pattern of translocation of protein kinase $\mathrm{C}$ delta fused to green fluorescent protein J Biol Chem 2000; 275:12136-46.

[21] Baryza JL, Brenner SE, Craske ML, Meyer T, Wender PA. Simplified analogs of bryostatin with anticancer activity display greater potency for translocation of PKCdelta-GFP. Chem Biol $2004 ; 11: 1261-7$.

[22] Appendino G, Spagliardi P, Ballero M, Seu G. Macrocyclic diterpenoids from Euphorbia hyberna L. subsp. insularis and their reaction with oxyphilic reagents. Fitoterapia 2002; 73:57682.

[23] Miglietta A, Gabriel L, Appendino G, Bocca C. Biological properties of jatrophane polyesters, new microtubule-interacting agents. Cancer Chemother Pharmacol 2003; 51:67-74.

[24] Corea G, Fattorusso E, Lanzotti V, Taglialatela-Scafati O, Appendino G, Ballero M, et al. Jatrophane diterpenes as P glycoprotein inhibitors. First insights of structure-activity relationships and discovery of a new, powerful lead. J Med Chem 2003; 46:3395-402.

[25] Márquez N, Calzado MA, Sánchez-Duffhues G, Pérez M, Minassi A, Pagani A, et al. Differential effects of phorbol-13-monoesters on human immunodeficiency virus reactivation. Biochem Pharmacol 2008; 75:1370-80. 
[26] Adachi A, Gendelman HE, Koening S, Folks T, Willey R, Rabson A, et al. Production of acquired immunodeficiency syndrome-associated retrovirus in human and non-human cells transfected with an infectious molecular clone. J Virol 1988; 59:284-91.

[27] Garcia-Perez J, Sanchez-Palomino S, Perez-Olmeda M, Fernandez B, Alcami J. A new strategy based on recombinant viruses as a tool for assessing drug susceptibility of human immunodeficiency virus type 1. J Med Virol 2007; 79:127-37.

[28] Arenzana-Seisdedos F, Fernandez B, Domínguez I, Jacque JM, Thomas D, Diaz-Meco MT, et al. Phosphatidylcholine hydrolysis activates NF-kappa B and increases human immunodeficiency virus replication in human monocytes and T lymphocytes. J Virol 1993; 67:6596-604.

[29] Oberlin E, Amara A, Bachelerie F, Bessia C, Virelizier JL, Arenzana-Seisdedos F, et al. The CXC chemokine SDF-1 is the ligand for LESTR/fusin and prevents infection by T-cell-lineadapted HIV-1. Nature 1996; 382:833-5.

[30] Oliva JL, Zarich N, Martínez N, Jorge R, Castrillo A, Azañedo M, et al. The P34G mutation reduces the transforming activity of K-Ras and N-Ras in NIH 3T3 cells but not of H-Ras. J Biol Chem 2004; 279:33480-91. 
[31] Laín de Lera T, Folgueira L, Martín AG, Dargemont C, Pedraza MA, Bermejo M, Bonay P, Fresno M, Alcamí J. Expression of IkB $\alpha$ in the nucleus of human peripheral blood T lymphocytes. Oncogene 1999; 18:1581-8.

[32] Szallasi Z, Krsmanovic L, Blumberg PM. Nonpromoting 12-deoxyphorbol 13-esters inhibit phorbol 12-myristate 13-acetate induced tumor promotion in CD-1 mouse skin. Cancer Res 1993; $53: 2507-12$

[33] Tuthill MC, Oki CE, Lorenzo PS. Differential effects of bryostatin 1 and 12-Otetradecanoylphorbol-13-acetate on the regulation and activation of RasGRP1 in mouse epidermal keratinocytes. Mol Cancer Ther 2006; 5:602-10.

[34] Jorge R, Zarich N, Oliva JL, Azañedo M, Martínez N, de la Cruz X, et al. HSos1 contains a new amino-terminal regulatory motif with specific binding affinity for its pleckstrin homology domain. J Biol Chem 2002; 277:44171-9.

[35] Philip PA, Harris AL. Potential for protein kinase C inhibitors in cancer therapy. In: F.M. Muggia Editor. Concepts, mechanisms and new targets for chemotherapy. Boston: Kluwer Academic Publishing, 1995. p. 3:28.

[36] Hornung RL, Pearson JW, Beckwith M, Longo DL. Preclinical evaluation of bryostatin as an anticancer agent against several murine tumor cell lines: in vitro versus in vivo activity. Cancer Res 1992; 52:101-7. 
[37] Hezareh M. Prostratin as a new therapeutic agent targeting HIV viral reservoirs. Drug News Perspect 2005; 18:496-500.

[38] Williams SA, Chen LF, Kwon H, Fenard D, Bisgrove D, Verdin E, et al. Prostratin antagonizes HIV latency by activating NF-kappaB. J Biol Chem 2004; 279:42008-17.

[39] Herdewijn P, Balzarini J, De Clercq E, Pauwels R, Baba M, Broder S, et al. 3'-substituted 2',3'-dideoxynucleoside analogues as potential anti-HIV (HTLV-III/LAV) agents. J Med Chem $1987 ; 30: 1270-8$.

[40] Bermejo M, Martin-Serrano J, Oberlin E, Pedraza MA, Serrano A, Santiago B, et al. Activation of blood $\mathrm{T}$ lymphocytes down-regulates CXCR4 expression and interferes with propagation of X4 HIV strains. Eur J Immunol 1998; 28:3192-204. 


\section{FIGURE LEGENDS}

Figure 1. Chemical structures. Chemical structures of the diterpene isolated from $E$. hyberna, SJ23B, and the phorbol esters derivatives phorbol myristate acetate (PMA) and prostratin.

Figure 2. Anti-HIV activity of SJ23B. A. MT-2 cells or PBMCs activated with CD3+IL2 for 48 hours were pre treated with different concentrations of SJ23B for two hours and infected for 2 additional hours with a recombinant X4 tropic virus (NL4.3-Renilla). Renilla-luciferase activity (RLUs) in cell lysates was measured 48 hours later. Results are expressed as \% RLUs versus infection performed in the absence of drug (Untreated cells were used as control). Viability was assessed by propidium iodide method or by CellTiter Glo viability assay (Promega). B. Activated PBMCs were pre treated for 2 hours with different concentrations of SJ23B and infected with a wild type X4 tropic virus (NL4.3) or with a recombinant X4 tropic virus (NL4.3Renilla) for 2 additional hours. Afterwards, cell culture was extensively washed with PBS and compounds were added again to the cell culture. HIV p24-gag protein was determined in culture supernatants 48 hours later. Results are expressed as \% p24-gag protein versus infection performed in the absence of drug. Viral production in control untreated cells was $10 \mathrm{ng}$ p24/ml (threshold of the test was $10 \mathrm{pg} \mathrm{p} 24 / \mathrm{ml})$. Table: Inhibitory concentration $50\left(\mathrm{IC}_{50}\right)$ and cytotoxic concentration $50\left(\mathrm{CC}_{50}\right)$ values for the panels described above were estimated using GraphPad software and Specificity index (SI) were calculated by the formula: $\mathrm{CC}_{50} / \mathrm{IC}_{50}$. C. Activated PBMCs were treated with different concentrations of SJ23B, and left in culture for two weeks. Every 48-72 hours, culture was washed and treatment was added again. Cell viability was measured at days 2, 6, 10 and 14 by CellTiter Glo (Promega) luminescence viability assay, and results are shown as percentage of viable cells as compared to a non treated culture. Apoptosis 
was evaluated by Anexin V expression in cell surface at days 2, 6, 10 and 14. Results are shown as percentage of Anexin V positive cells.

\section{Figure 3. SJ23B inhibits HIV replication at lower concentrations than prostratin.}

Activated PBMCs were infected with X4 or R5 recombinant HIV carrying the Renilla-luciferase gene as reporter (NL4.3-Renilla and JR-Renilla, respectively). Cultures were pre-treated for 2 hours before infection with SJ23B or Prostratin at two concentrations $(0.1$ and $1 \mu \mathrm{M})$ and left in culture for 48 hours. Luciferase activity was measured 48 hours after infection.

\section{Figure 4. SJ23B downregulates HIV receptors in PBMCs.}

A. Expression of CD4, CCR5, CXCR4 receptors was analyzed in PBMCs activated with antiCD3 + IL-2 for 48 hours. Afterwards cells were treated with either SJ23B at 0.1 or $1 \mu \mathrm{M}$ or PMA $(0.04 \mu \mathrm{M})$. Expression of receptors was measured by using specific monoclonal antibodies at different points along drug treatment $(2,5,24$ and 48 hours). Results are shown receptor mean fluorescence intensity in cell cultures (upper pannels) and as percentage of expression (lower pannels). Values are representative of at least three independent experiments. PBMCs were analyzed using forward-versus-side scatter dot plots.

B. Expression of HLA-1 and CD69 was studied in resting PBMCs treated with either SJ23B at 0.1 or $1 \mu \mathrm{M}$ or PMA $(0.04 \mu \mathrm{M})$. Expression of receptors was measured by using specific monoclonal antibodies at different points along drug treatment $(2,5,24$ and 48 hours). Results are shown and as receptor mean fluorescence intensity in cell cultures (upper pannels) and as percentage of expression (lower pannels). Values are representative of at least three independent experiments. PBMCs were analysed using forward-versus-side scatter dot plots. 


\section{Figure 5. Inhibition of HIV infection by SJ23B is related to down-regulation of viral} receptors. PBMCs previously activated with CD3+IL-2 for 48 hours were treated with PMA $(0.04 \mu \mathrm{M})$ or SJ23B $(0.1$ and $1 \mu \mathrm{M})$ for five hours or left untreated. Cell cultures were then infected overnight with either X4 (NL4.3 Renilla), R5 (JR Renilla) tropic or VSV pseudotyped (NL4.3- $\Delta$-env-VSV-Luc) recombinant viruses (VA: Virus adsorption). Afterwards, PBMCs were left in culture. Non-infected (_) and infected but non-treated $(\bullet-)$ cultures were used as controls. A) Expression of CD4, CXCR4 and CCR5 in activated PBMCs. CCR5, CXCR4 and CD4 expression was measured at different times during treatment ( 0,4 and 7 days). Results are shown as percentage of cells expressing the receptor and are representative values of at least three independent experiments. PBMCs were analyzed using forward-versus-side scatter dot plots. B) Inhibition of HIV replication by SJ23B. HIV infection was measured at day 4 by luminometry in the same culture used to evaluate receptor expression and it is expressed as percentage of RLUs in infected cultures as compared to non-treated cultures.

\section{Figure 6. SJ23B antagonizes HIV-1 latency through a PKC-dependent pathway. A)}

Jurkat LAT-GFP cells were stimulated with either prostratin or SJ23B at the indicated concentrations for 6 hours, and next analysed by flow cytometry. Results are represented as the percentage of GFP positive cells \pm SD of three different experiments. B) Jurkat LAT-GFP cells were pretreated with the indicated inhibitors for $30 \mathrm{~min}$ at the indicated dose, and then stimulated with SJ23B $(1 \mu \mathrm{M})$ for $6 \mathrm{~h}$. The percentage of GFP+ cells was measured by flow cytometry. Results are represented as percentage of activation \pm SD compared to cells treated with agonists in the absence of the chemical inhibitors (100\% activation). C) Activation of PKC $\alpha$ and PKC $\delta$ by SJ23B. PKC $\alpha$ and $\mathrm{PKC} \delta$ activities were assayed in the presence phospholipid vesicles $(20 \%$ 
phosphatidylserine, $80 \%$ phosphatidylcholine) and increasing concentration of SJ23B. Results are expressed as percentage of the activation observed with $1 \mu \mathrm{M}$ PMA (100\%) and represent the mean \pm S.E. of triplicate determination in a single experiment. Two additional experiments gave similar results.

Figure 7. SJ23B induced degradation of IאB $\alpha$ and strong NF- $\kappa B$ binding to DNA. A) The cells were pretreated with the inhibitors as indicated and then stimulated with SJ23B for $15 \mathrm{~min}$. Total cell extracts were analysed by Western Blot with specific antibodies. B) Effect of SJ23B on NF-kB-DNA binding activity. Jurkat LAT-GFP cells were incubated either with PMA (50 $\mathrm{ng} / \mathrm{ml})$ or with increasing concentrations of SJ23B in the presence or absence of Go6976 $(1 \mu \mathrm{M})$ or Rottlerin $(40 \mu \mathrm{M})$ for $30 \mathrm{~min}$. Nuclear extracts were then assayed by EMSA using a labelled $\mathrm{NF}-\kappa \mathrm{B}$ oligonucleotide.

\section{Figure 8. SJ23B translocates PKCa-GFP to the plasma membrane and synergizes with} ionomycin to activate NF-kB A) Fluorescent images of CHO-K1 cells expressing the $\mathrm{PKC} \alpha$ GFP protein treated at $37{ }^{\circ} \mathrm{C}$ for 10 min with either PMA $(1 \mu \mathrm{M})$ or with increasing concentrations of SJ23B in the absence or the presence of ionomycin $(0.5 \mu \mathrm{M})$. Three additional experiments gave similar results. B) Jurkat LAT-GFP cells were incubated either with PMA (50 $\mathrm{ng} / \mathrm{ml})$ or with increasing concentrations of SJ23B in the presence or absence of ionomycin $(0.5$ $\mu \mathrm{M})$ for $30 \mathrm{~min}$. Nuclear extracts were then assayed as in Figure 7.

Figure 9. Effect of SJ23B on foci formation in NIH 3T3 cells. NIH 3T3 fibroblasts were treated either with PMA, or Prostratin, or SJ23B, or transfected with pCEFL-KZ-HA-K-Ras V12 
(K-RasV12) at concentrations described in the Figure. Foci formation is evident when NIH 3 T3 cells were transfected with KRasV12, or treated with PMA.

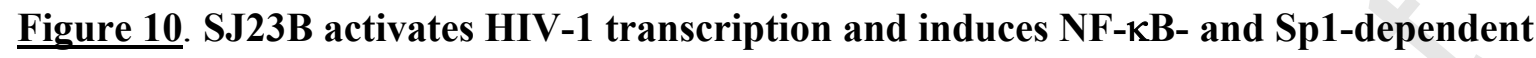
gene expression. Resting PBMCs were transfected with different luciferase constructs under the control of full-length HIV DNA (NL4.3-Luc), three tandem $\kappa$ B consensus repeats (3-enhancer$\kappa \mathrm{B}-\mathrm{ConA}-\mathrm{Luc})$ and Sp1 (Sp1-Luc) in the presence of SJ23B $(0.1$ and $1 \mu \mathrm{M})$, prostratin $(0.1$ and $1 \mu \mathrm{M})$ and PMA $(0.04 \mu \mathrm{M})$. After 48 hours, RLUs were measured and results were expressed as fold versus transfected and non-activated PBMCs.

Figure 11. Chemical structures of the jatrophane diterpenes used in the study and $\mathrm{IC}_{50}$ values for HIV-1 reactivation in Jurkat-LAT-GFP cells. 
Figure 1

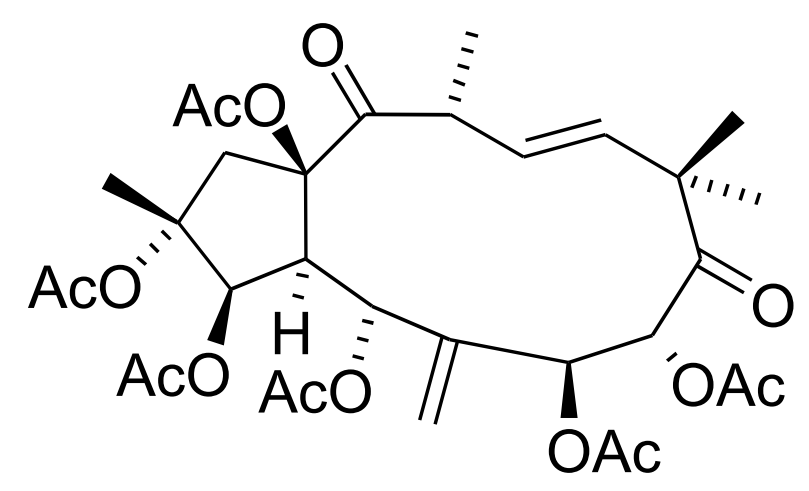

SJ23B

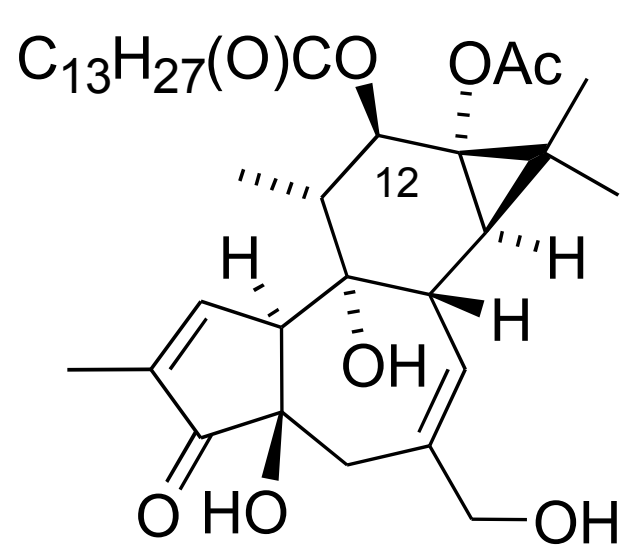

PMA

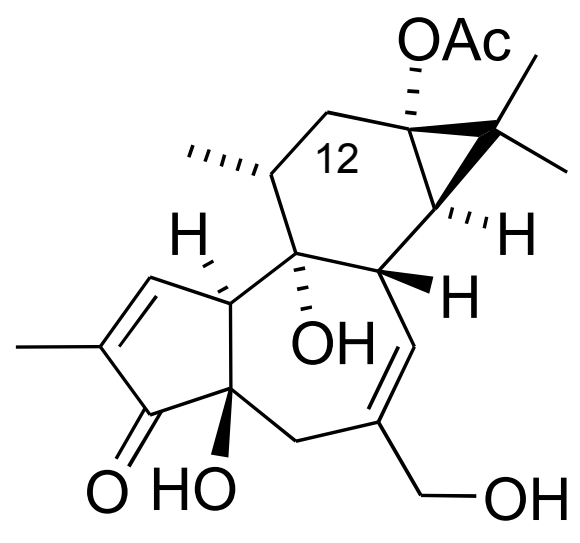

PROSTRATIN 
Figure 2

A

MT-2

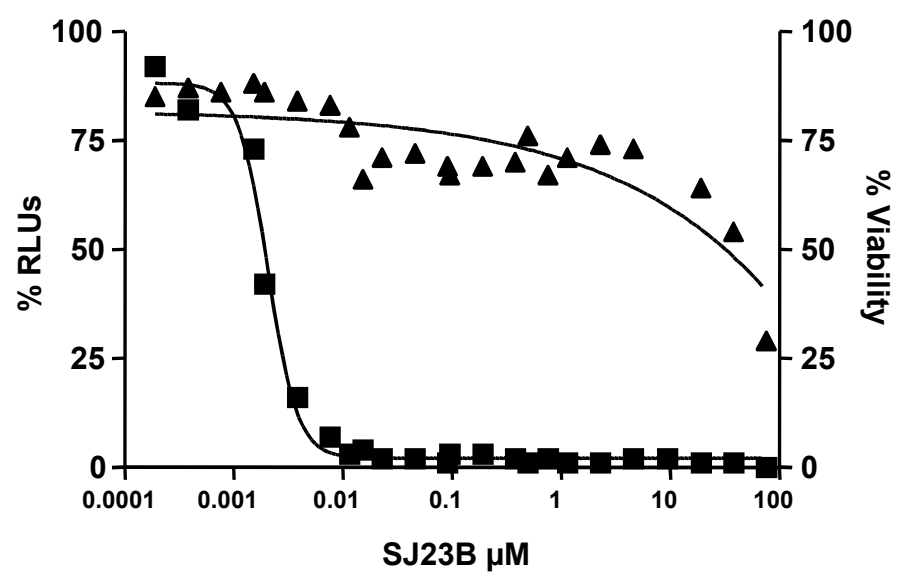

NL4.3-Ren $\Delta$ Viability
PBMCs

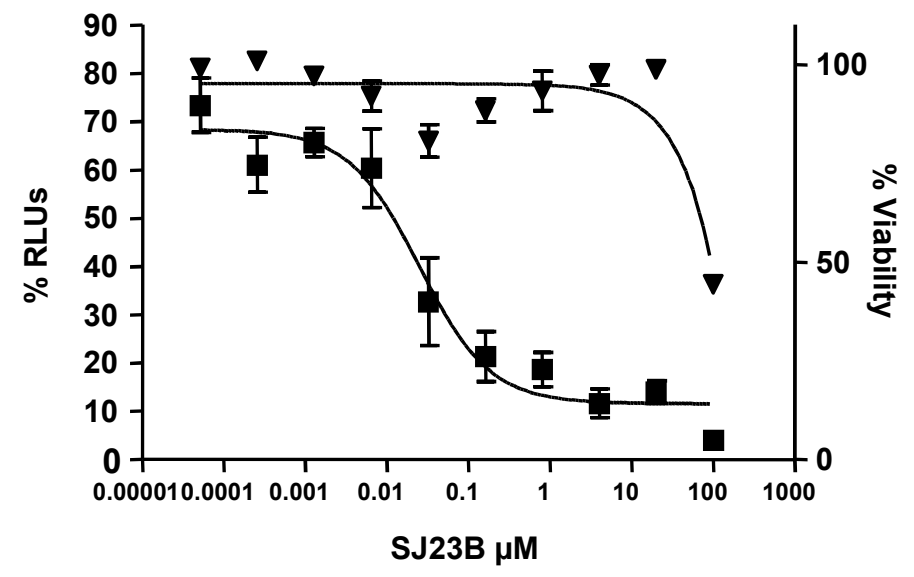

NL4.3-Ren $\Delta$ Viability

\section{B}

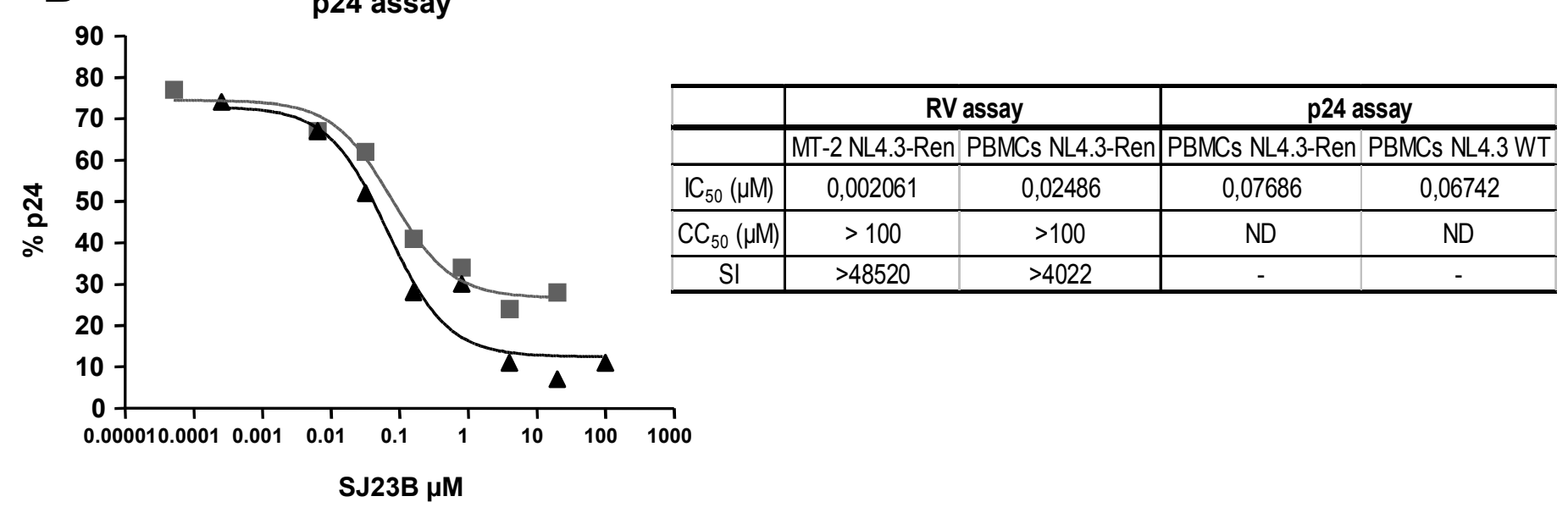

C

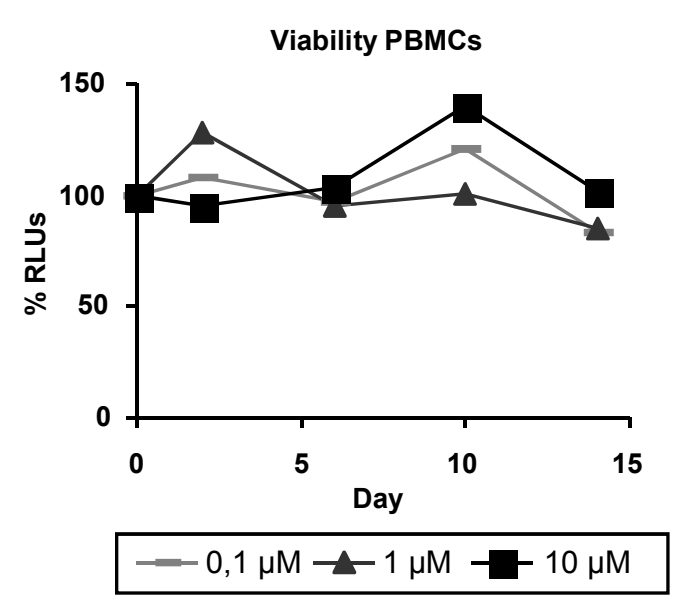

Apoptosis PBMCs

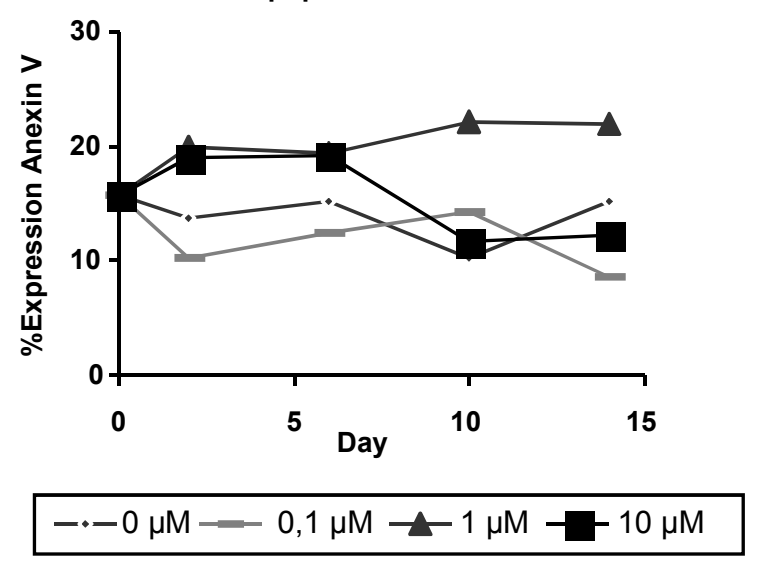


Figure 3
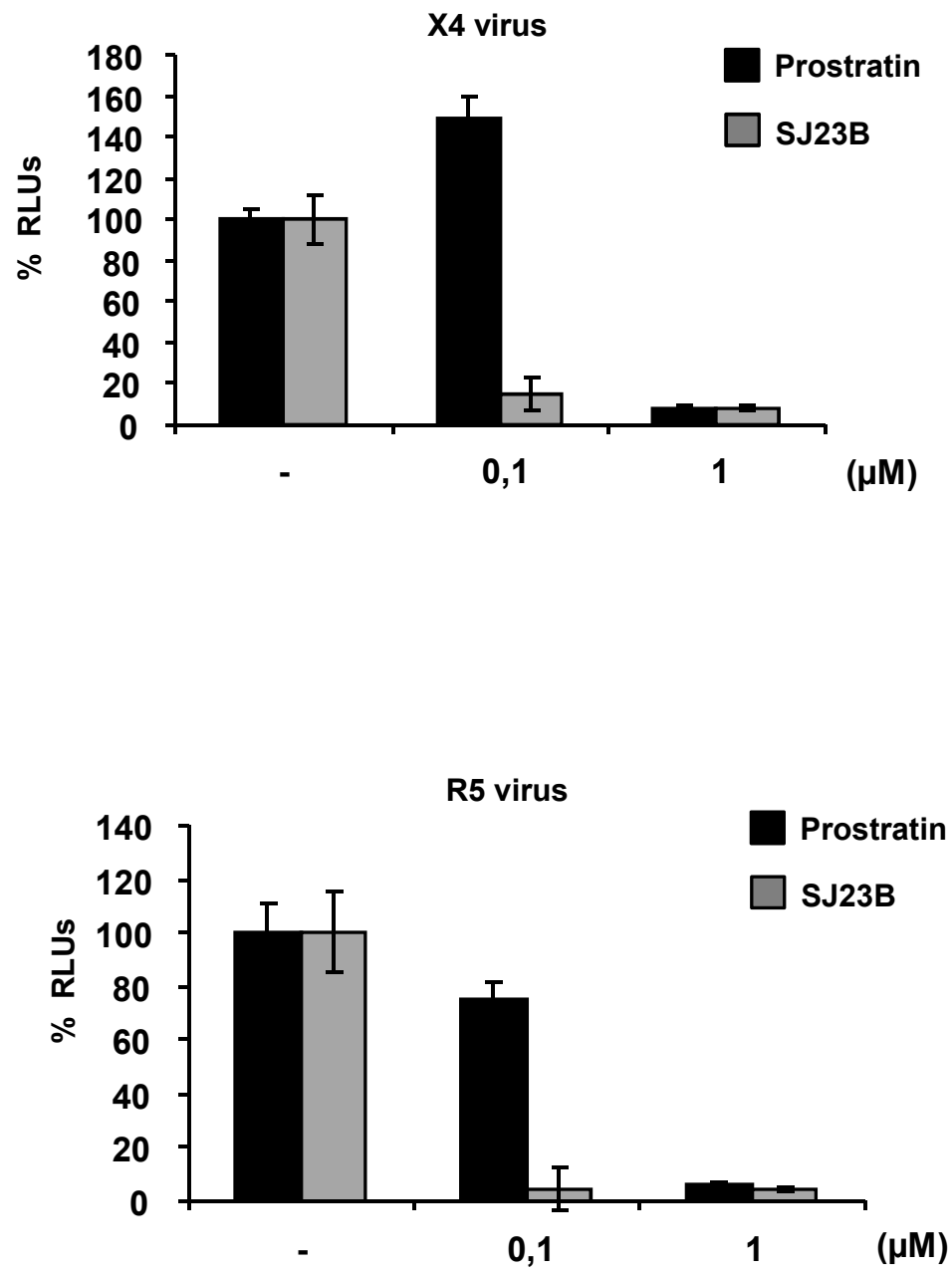
Figure 4
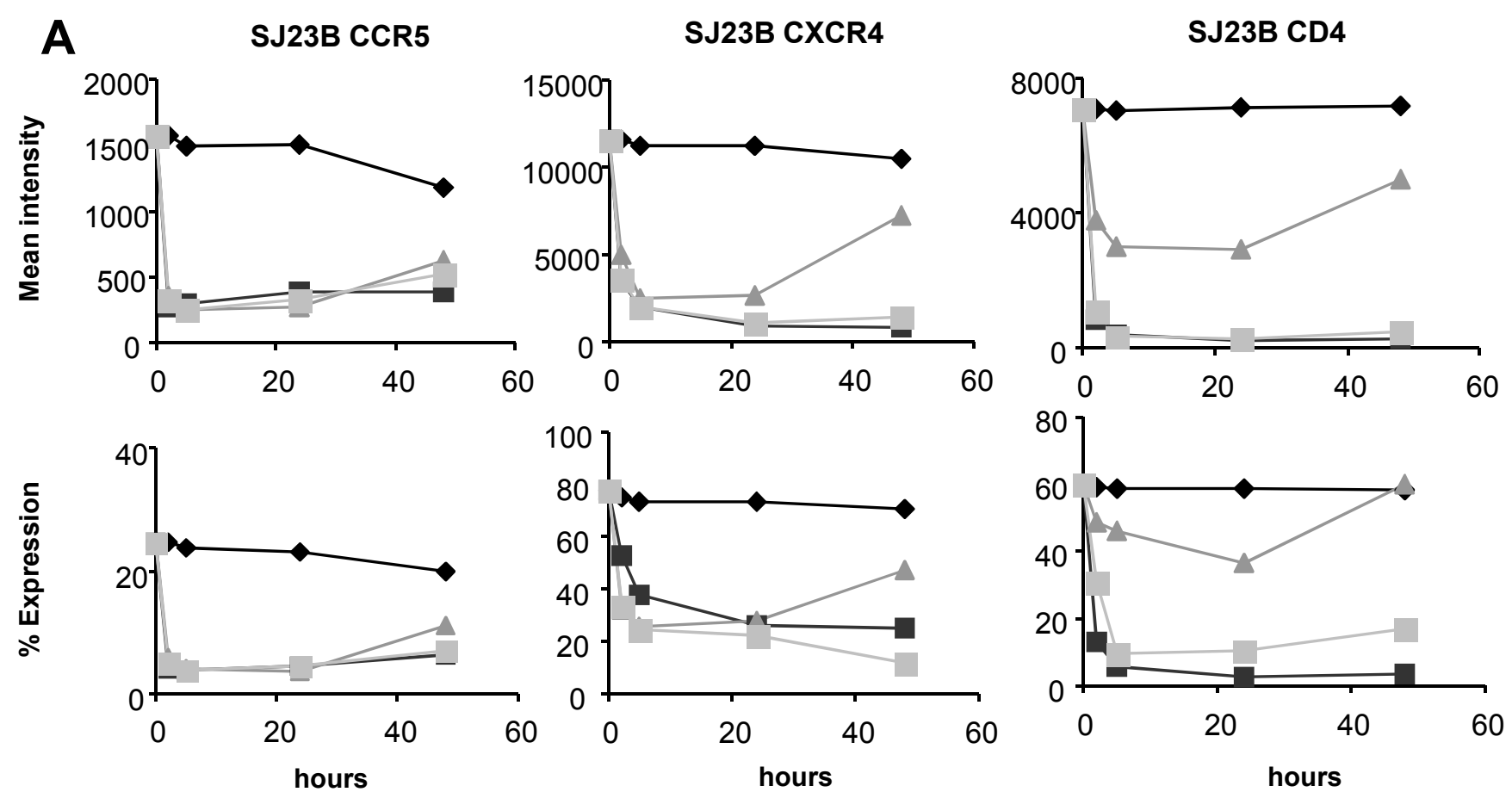

$$
\neg \text { Control } \rightarrow \text { PMA } \leftarrow 0,1 \mu \mathrm{M} \backsim 1 \mu \mathrm{M}
$$

B

SJ23B CD69
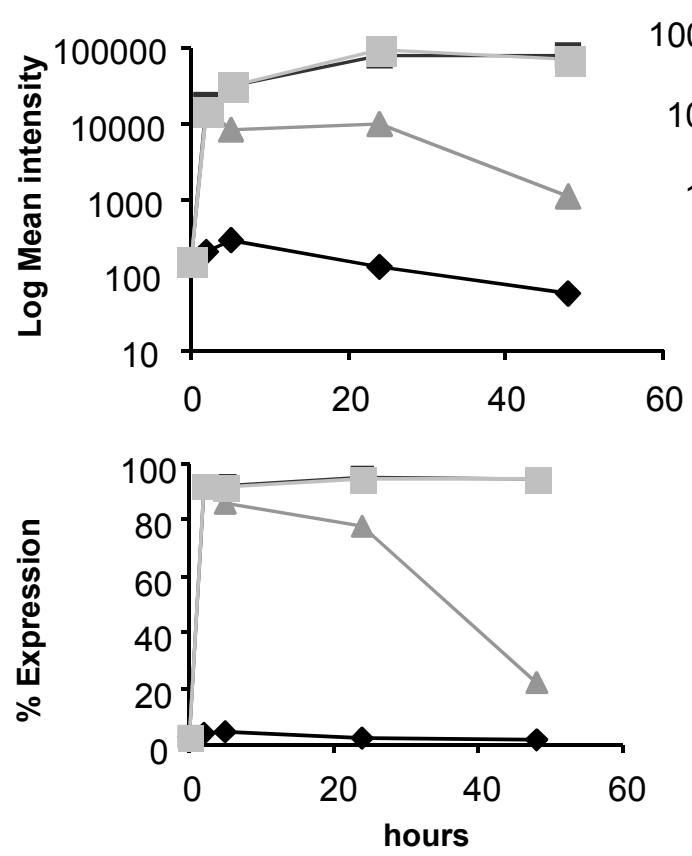

SJ23B MHC-1
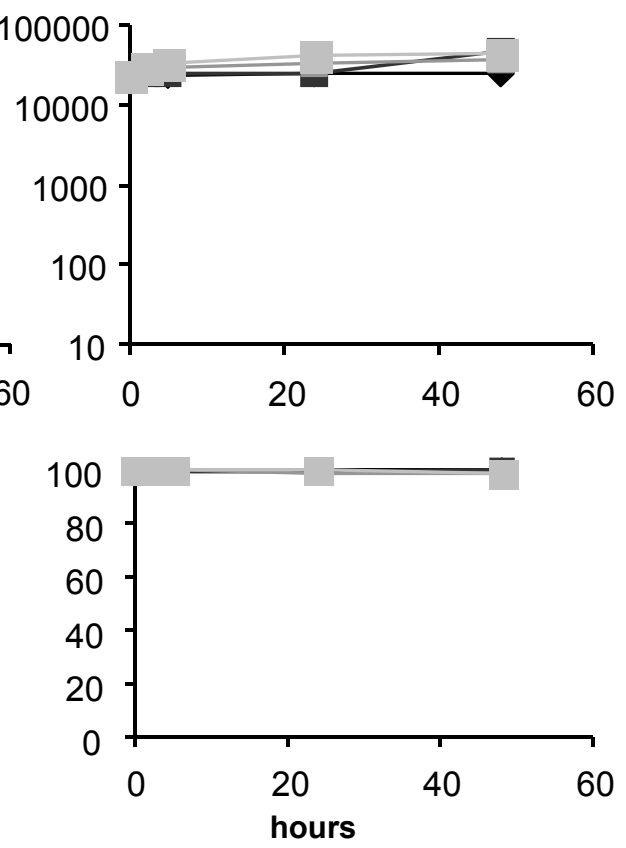

$$
\leadsto \text { Control } \rightarrow \text { PMA } \leftarrow 0,1 \mu \mathrm{M} \rightarrow-1 \mu \mathrm{M}
$$


Figure 5

A

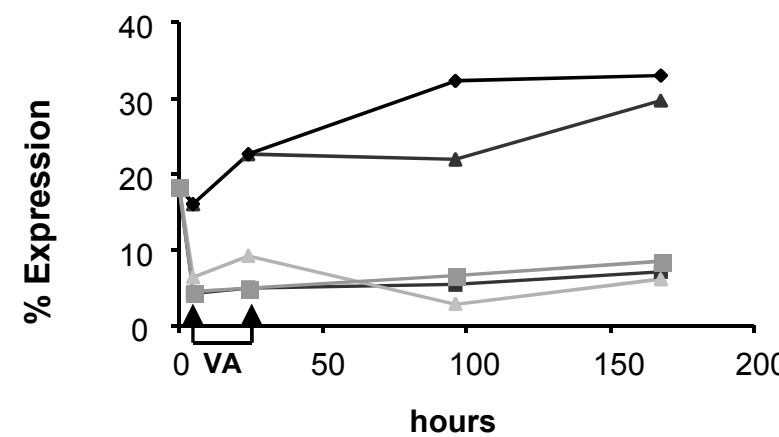

CD4 expression R5 infected

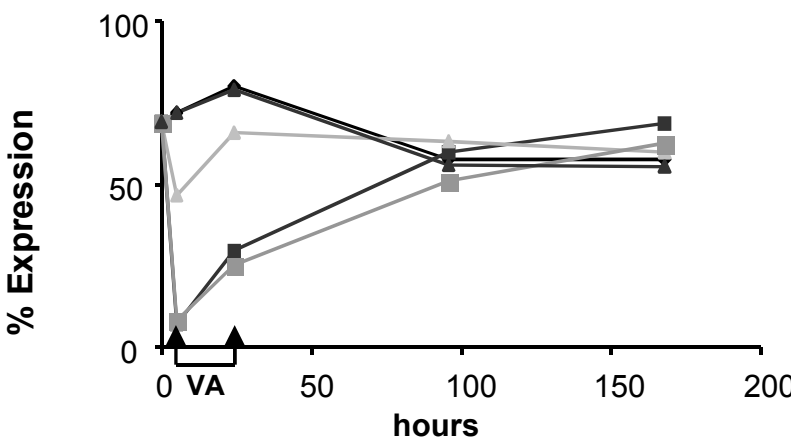

hours

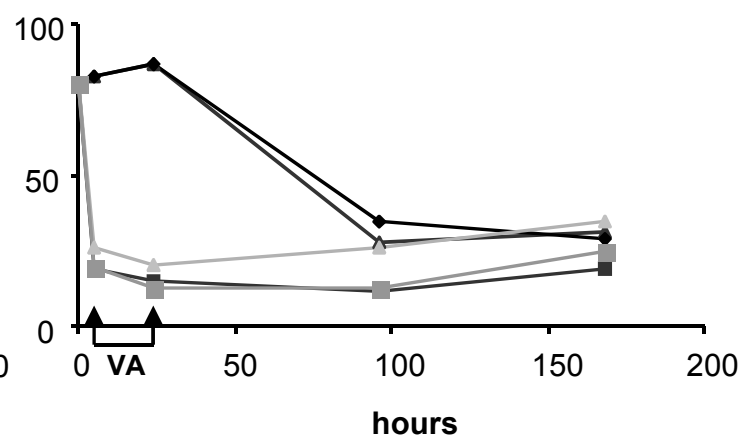

CD4 expression X4 infected

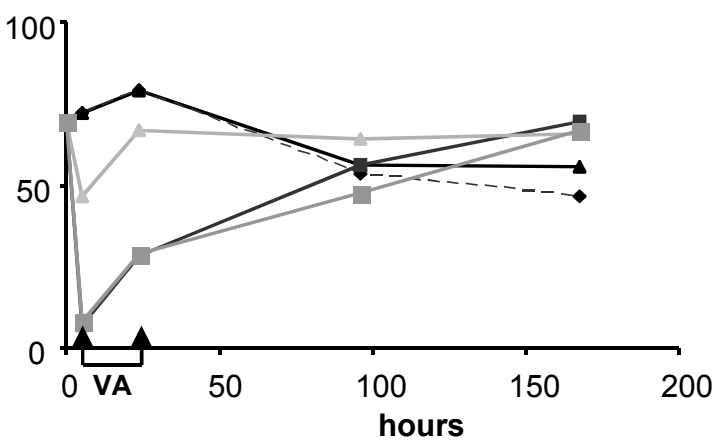

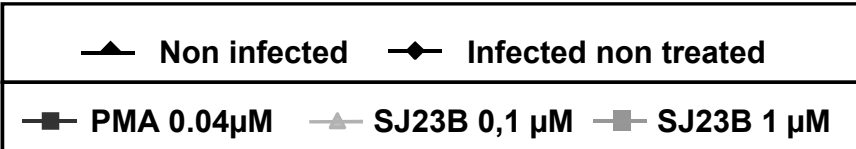

B

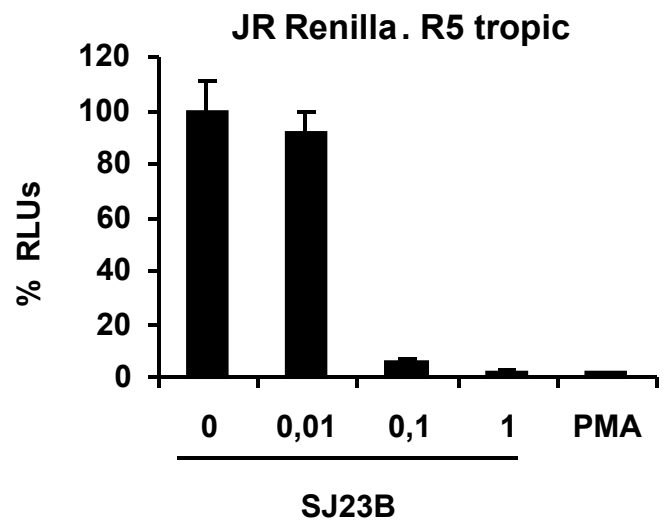

NL4.3-Renilla. X4 tropic

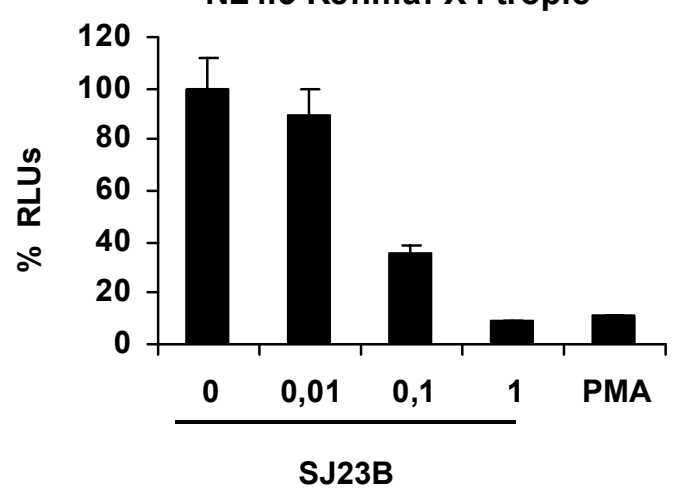

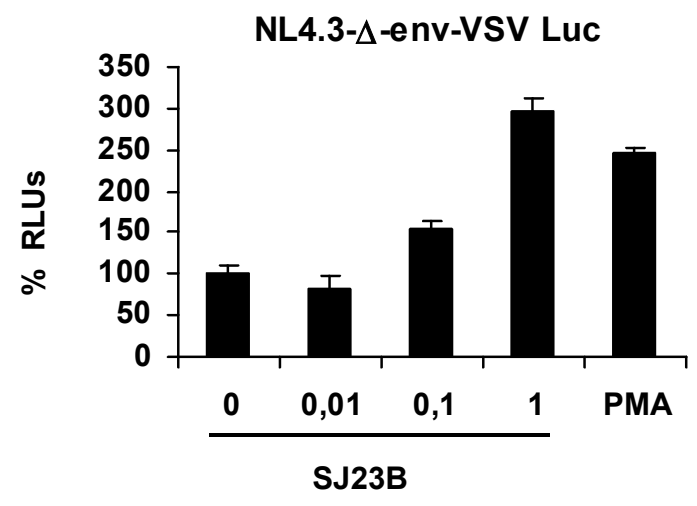


Figure 6

A

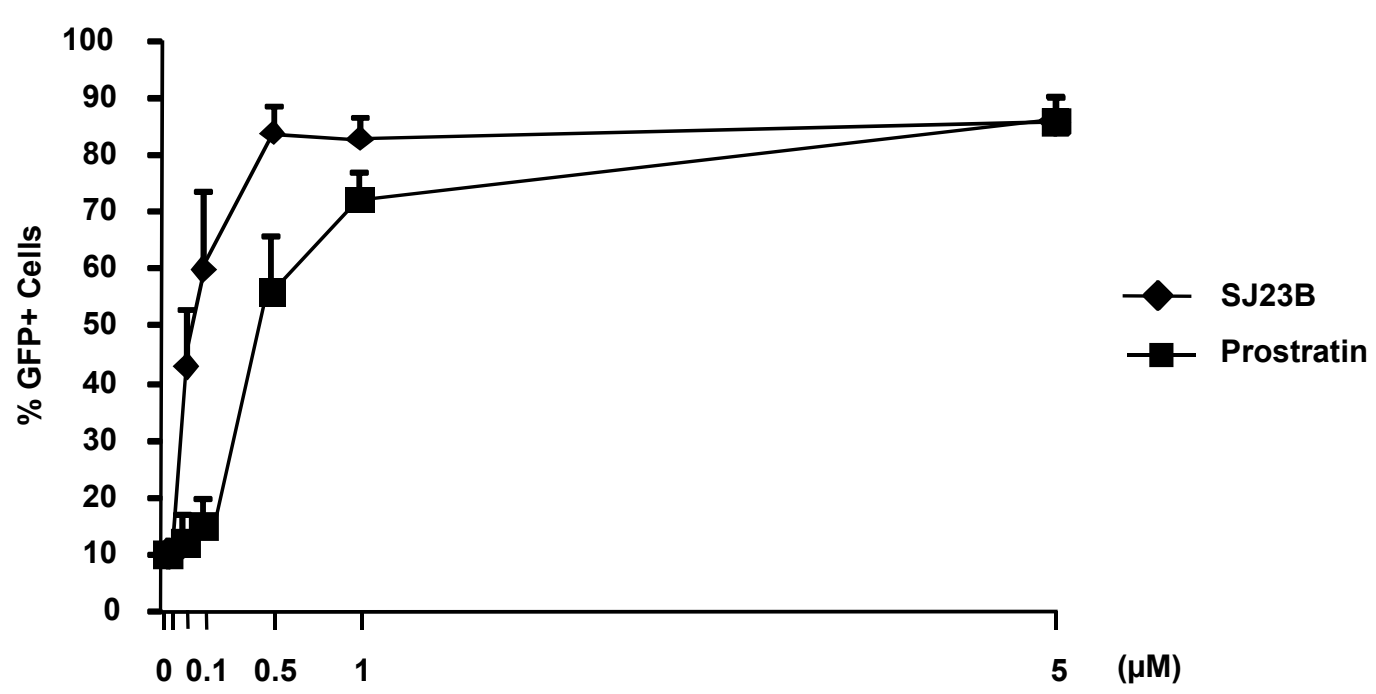

B

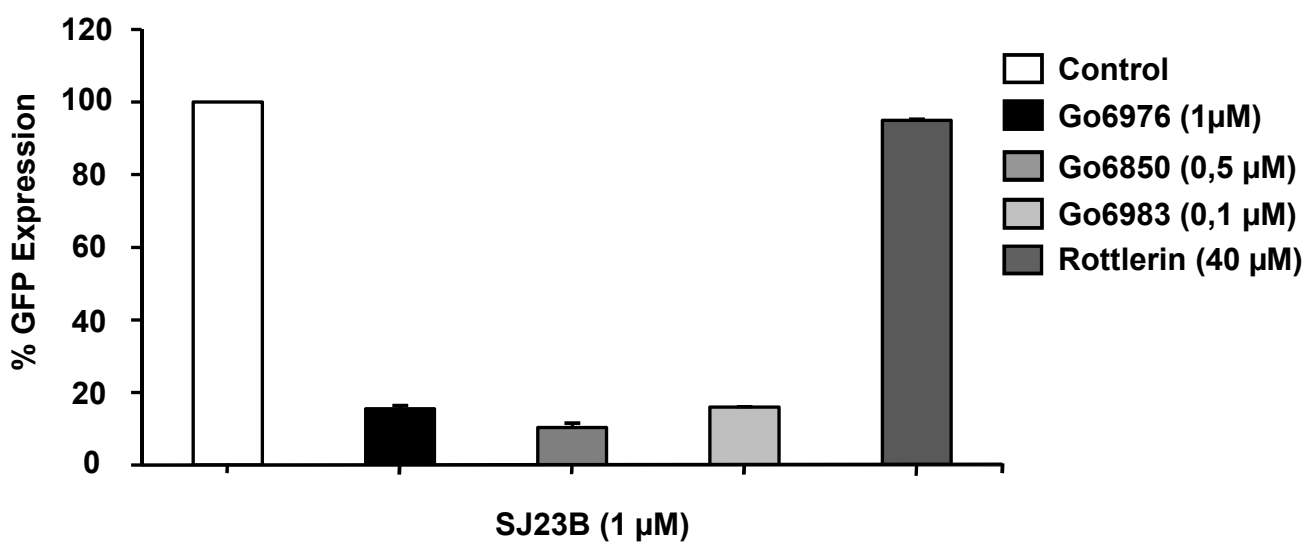

C

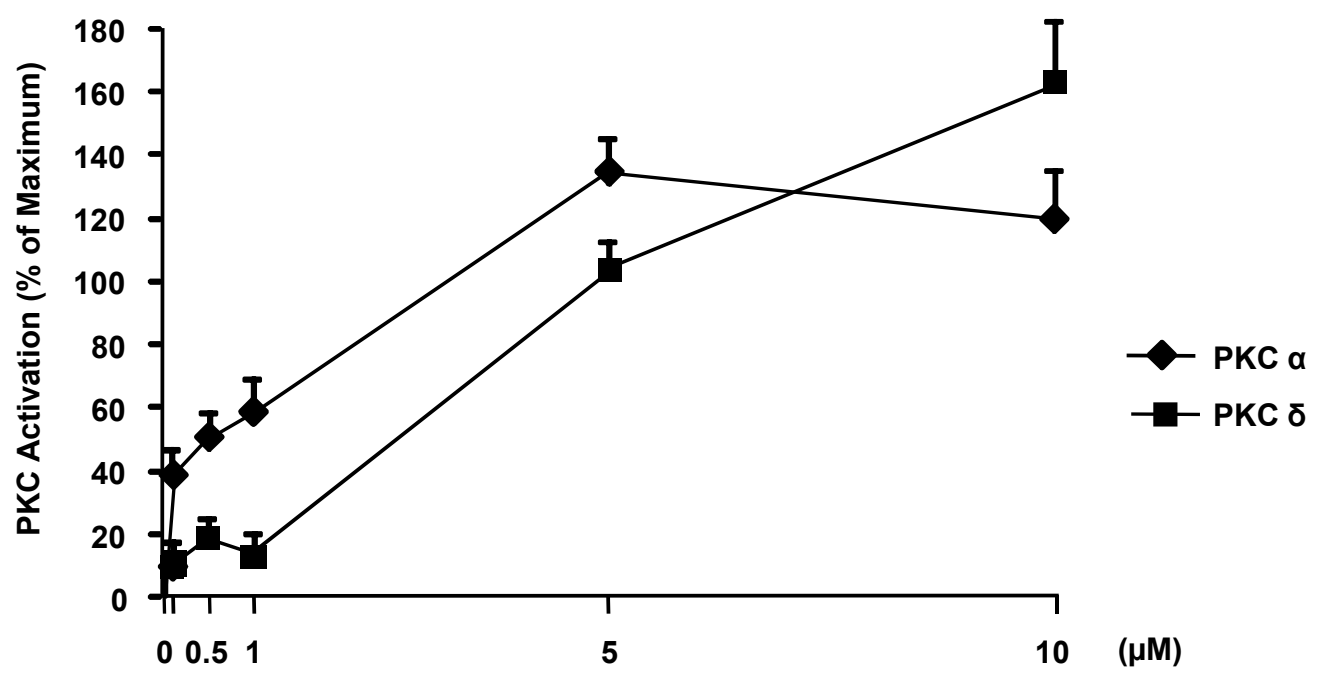


Figure 7

A

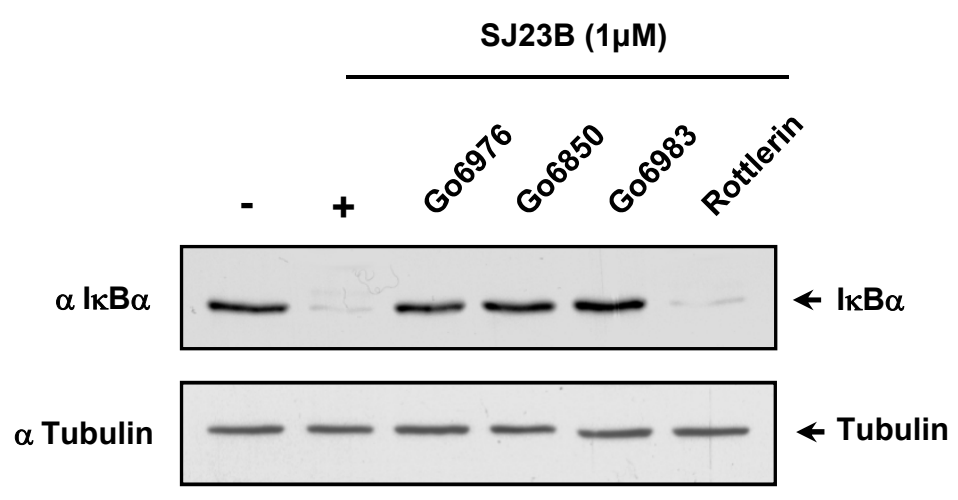

B

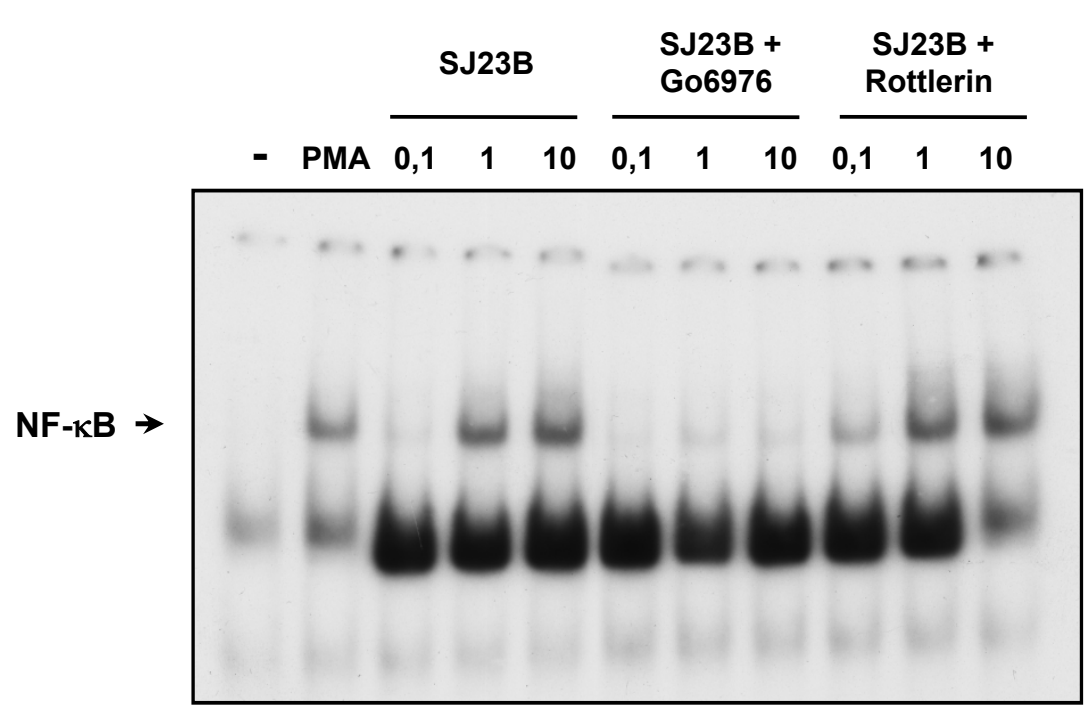


Figure 8

A

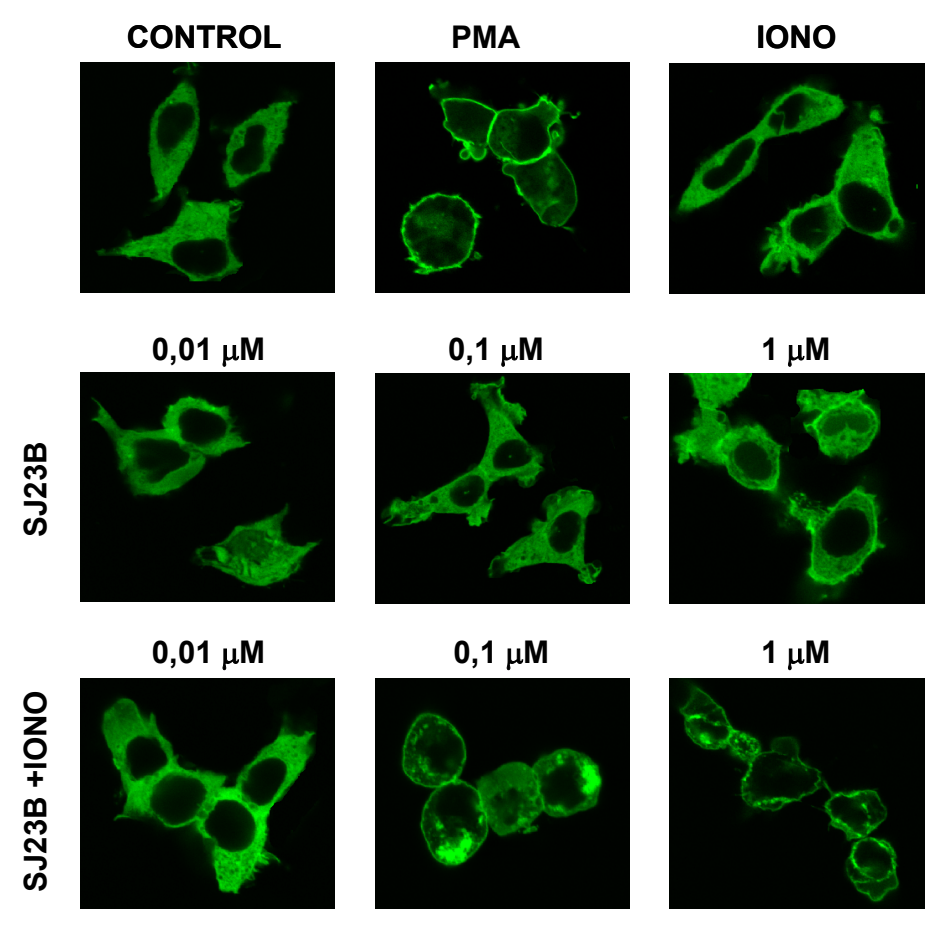

B

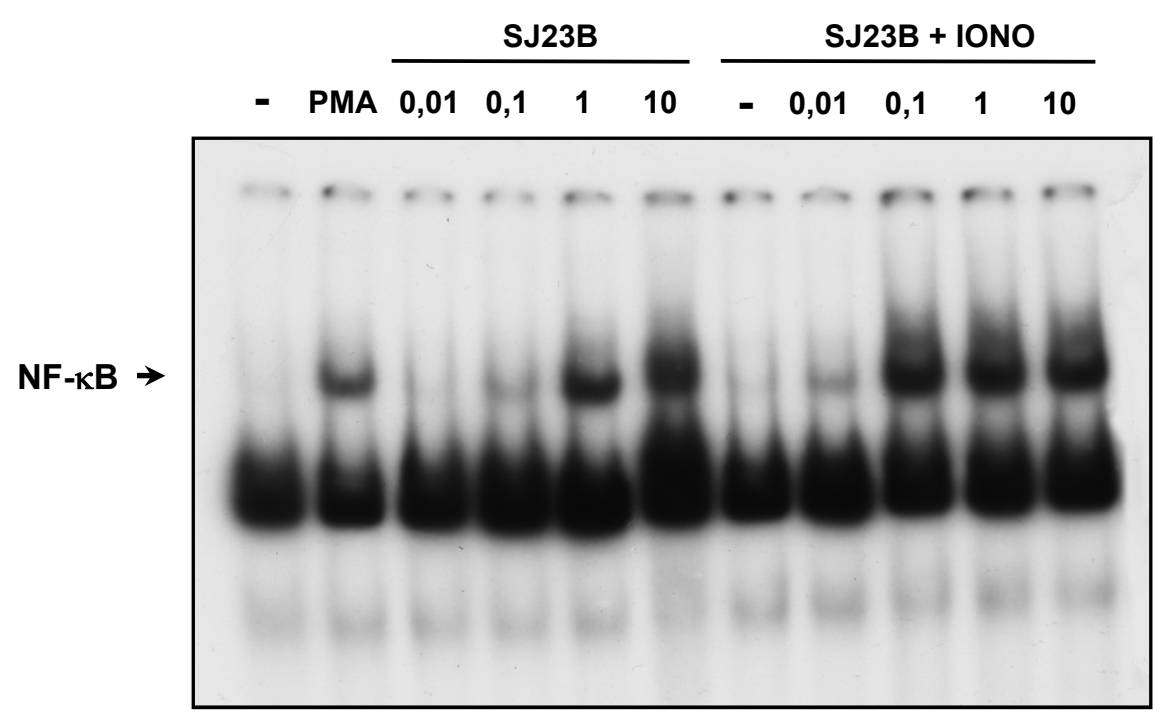


Figure 8

A

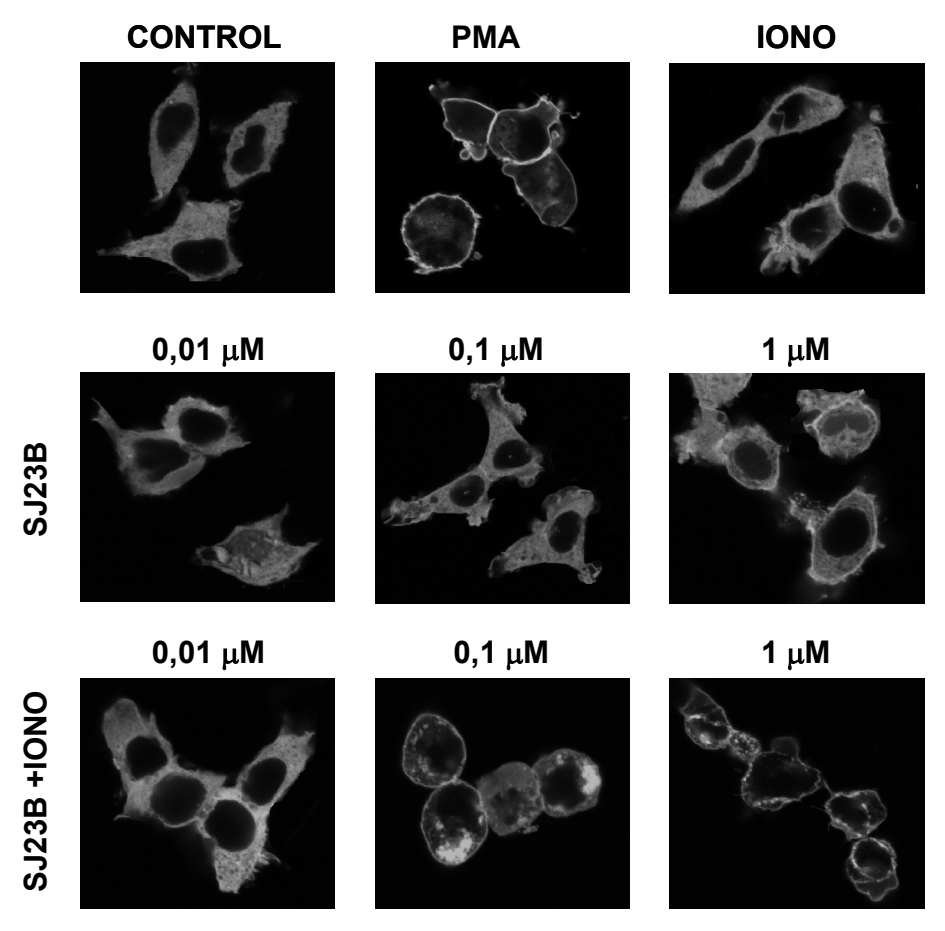

B

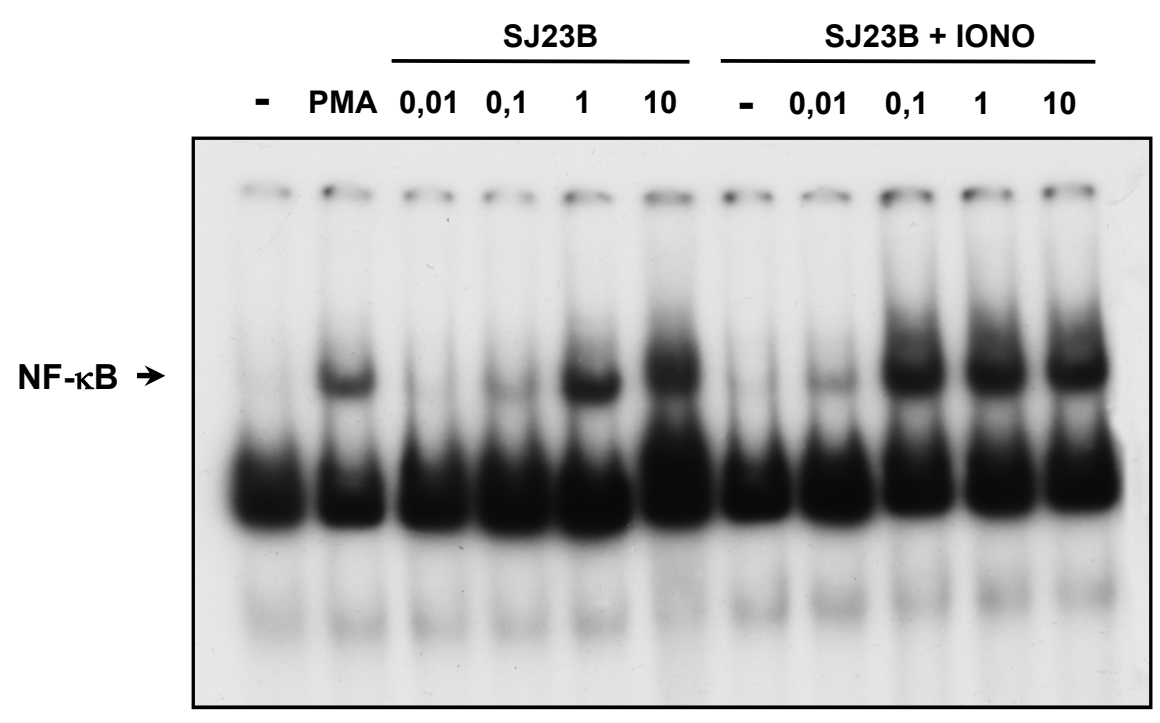


Figure 9
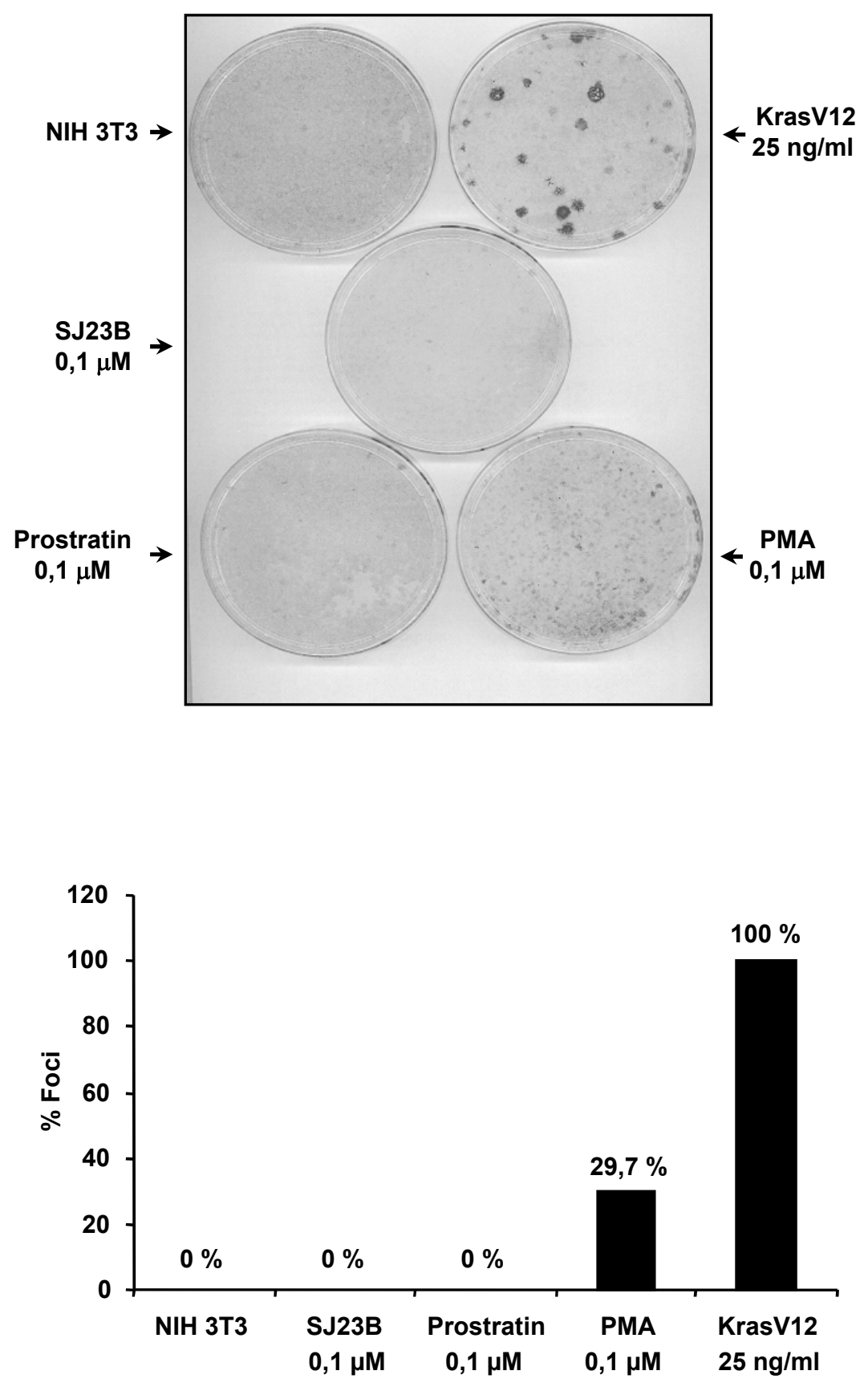
Figure 10
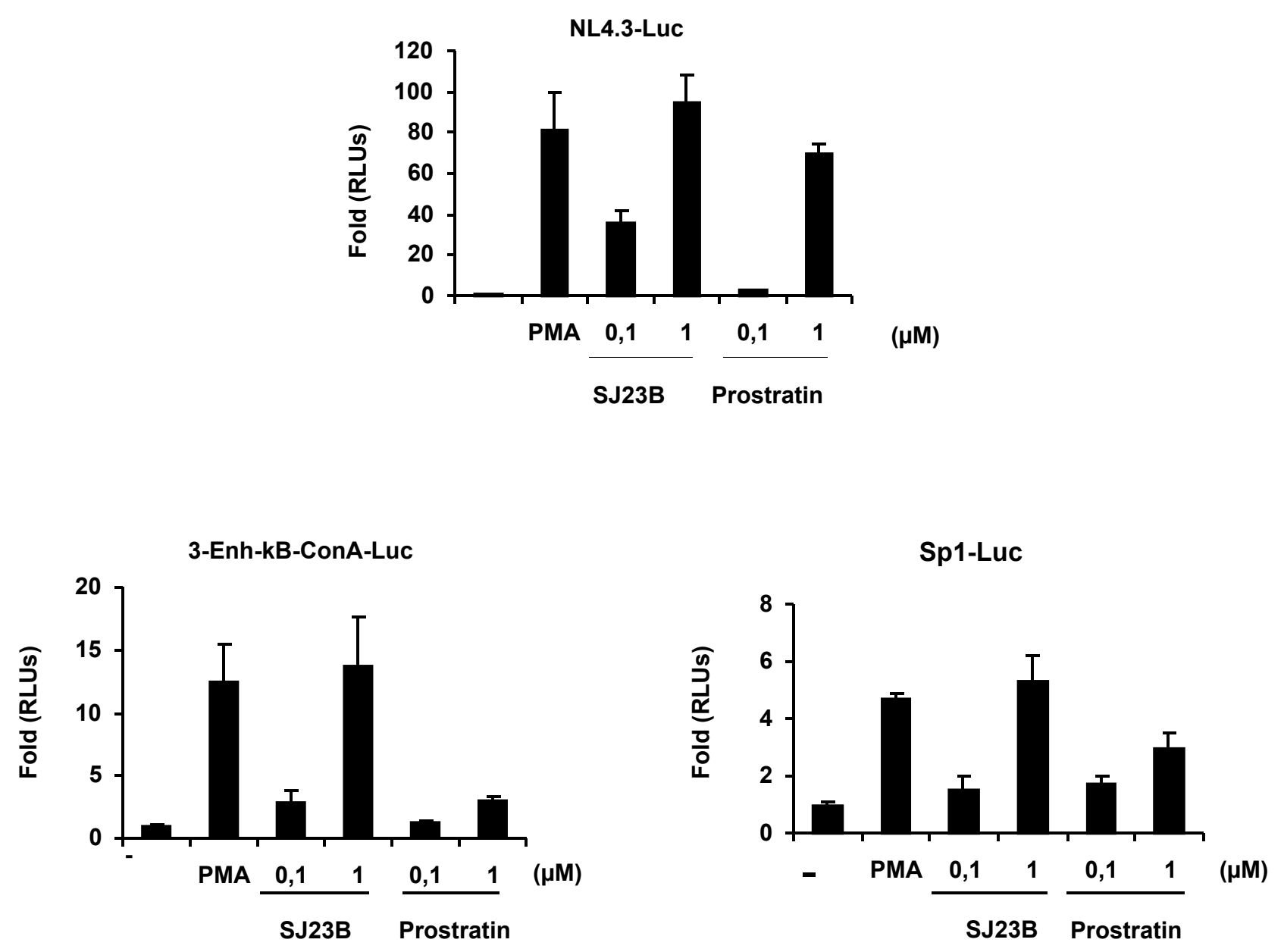
Figure 11
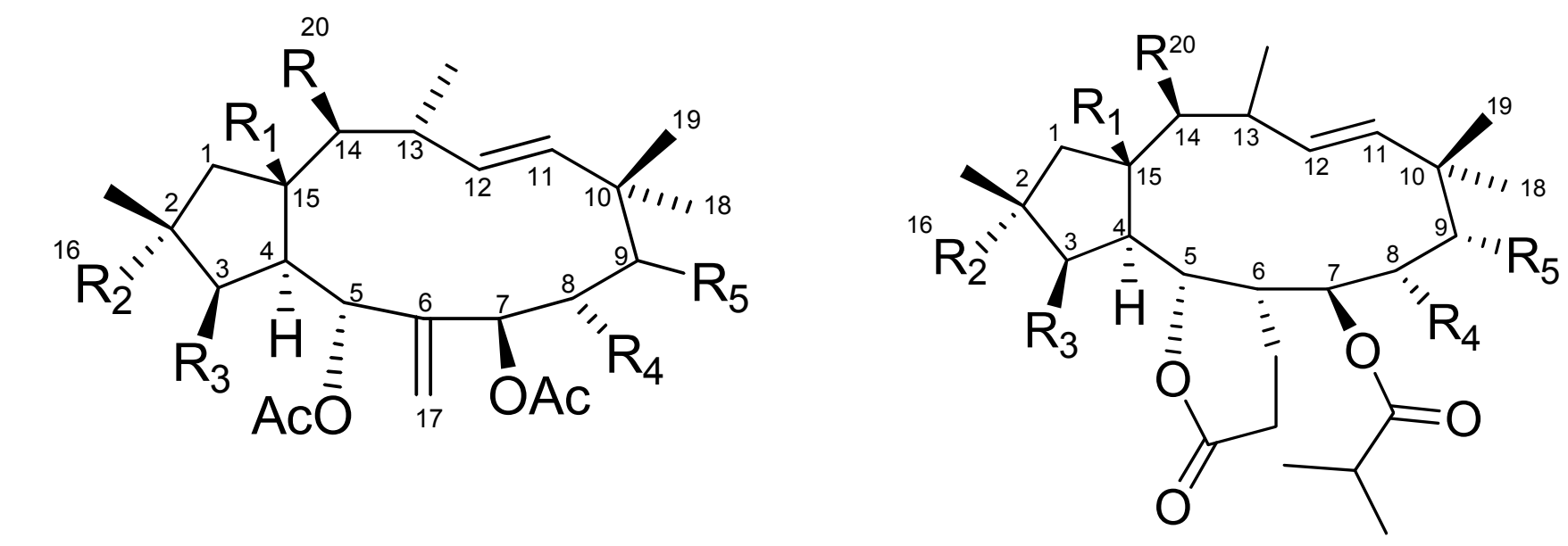

\begin{tabular}{|c|c|c|c|c|c|c|c|}
\hline & $\mathbf{R}$ & $\mathbf{R}_{1}$ & $\mathbf{R}_{\mathbf{2}}$ & $\mathbf{R}_{\mathbf{3}}$ & $\mathbf{R}_{\mathbf{4}}$ & $\mathbf{R}_{\mathbf{5}}$ & $\begin{array}{c}\text { HIV-1 REACTIVATION } \\
\text { EC50 }(\mu \mathrm{M})\end{array}$ \\
\hline$S J-13 c$ & $-O A C$ & $-\mathrm{OH}$ & $-H$ & $-O B z$ & $-H$ & $=0$ & $>50$ \\
\hline$S J-13 d$ & $-O A C$ & $-\mathrm{OH}$ & $-H$ & $-O B z$ & $\cdots \cdot \cdot \mathrm{CO}_{2} \mathrm{C}_{3} \mathrm{H}_{7}$ & $=0$ & $>50$ \\
\hline$S J-13 e$ & -OAc & $-\mathrm{OH}$ & $-H$ & $-O B z$ & $\ldots \cdot \cdots$ OAc & $=0$ & $>50$ \\
\hline$S J-23 b$ & $-O A C$ & $-O A C$ & .....'OAc & $-O A C$ & ...' OAC & $=0$ & 0,25 \\
\hline SJ-27a & $-\mathrm{OH}$ & $-\mathrm{OH}$ & $-H$ & $-O B z$ & $\ldots \cdot$ OAc & $=0$ & $>50$ \\
\hline$S J-29 b$ & -OAC & $-\mathrm{OH}$ & $-H$ & $-O B z$ & $-H$ & ....'OH & $>50$ \\
\hline Terracinolide C & $=0$ & -OAc & $\ldots \cdot \cdot$ OAc & $-\mathrm{OH}$ & $\ldots \cdot \cdot$ OAc & ...'OAC & 10 \\
\hline
\end{tabular}

